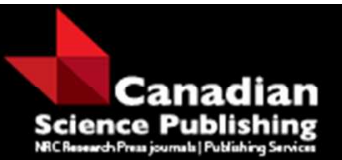

Canadian Journal of Physiology and Pharmacology Revue canadienne de physiologie et pharmacologie

\title{
Cannabinoid Signaling in Health and Disease
}

\begin{tabular}{|r|l|}
\hline Journal: & Canadian Journal of Physiology and Pharmacology \\
\hline Manuscript ID & cjpp-2016-0346.R1 \\
\hline Manuscript Type: & Review \\
\hline Date Submitted by the Author: & 24-Aug-2016 \\
\hline Complete List of Authors: & $\begin{array}{l}\text { Lu, Yan; University of Manitoba, Faculty of Pharmacy; St. Boniface } \\
\text { Research Centre, CCARM } \\
\text { Anderson, Hope; St. Boniface Research Centre, }\end{array}$ \\
\hline Keyword: & endocannabinoid, cannabinoid receptor, anandamide, FAAH, MAGL \\
\hline \multicolumn{2}{|l}{} \\
\hline
\end{tabular}

\section{SCHOLARONE ${ }^{\text {m }}$}

Manuscripts 


\title{
Cannabinoid Signaling in Health and Disease
}

\author{
Yan $\mathrm{Lu}^{\mathrm{a}, \mathrm{b}}$ and Hope D. Anderson ${ }^{\mathrm{a}, \mathrm{b}, \mathrm{c}, \mathrm{d}}$
}

${ }^{\mathrm{a} C}$ College of Pharmacy, Rady Faculty of Health Sciences, University of Manitoba. 750 McDermot Avenue, Winnipeg, Canada. R3E 0T5.

${ }^{\mathrm{b}}$ Canadian Centre for Agri-Food Research in Health and Medicine, St. Boniface Hospital Research Centre. 351 Taché Avenue, Winnipeg, Canada. R2H 2A6.

${ }^{\mathrm{c}}$ Department of Pharmacology and Therapeutics, Max Rady College of Medicine, University of Manitoba. 753 McDermot Avenue, Winnipeg, Canada. R3E 0T6.

d corresponding author: ｅmail: handerson@sbrc.ca

telephone: 204-235-3587

fax: $\quad 204-237-4018$ 
Abstract

Cannabis sativa has long been used for medicinal purposes. To improve safety and efficacy, compounds from $C$. sativa were purified or synthesized and named under an umbrella group as cannabinoids. Currently, several cannabinoids may be prescribed in Canada for a variety of indications such as nausea and pain. More recently, an increasing number of reports suggest other salutary effects associated with endogenous cannabinoid signaling including cardioprotection. The therapeutic potential of cannabinoids is therefore extended; however, evidence is limited and mechanisms remain unclear. In addition, the use of cannabinoids clinically has been hindered due to pronounced psychoactive side effects.

This review provides an overview on the endocannabinoid system, including known physiological roles, and conditions in which cannabinoid receptor signaling has been implicated.

Keywords: endocannabinoid, cannabinoid receptor, anandamide, 2-arachidonoylglycerol, FAAH, MAGL 


\section{Introduction}

Cannabis sativa has long been used to relieve symptoms such as pain, fever, anxiety, and diarrhea in the context of numerous diseases (Grant et al. 2012). To improve safety and efficacy, compounds from $C$. sativa were purified or synthesized and named under an umbrella group as cannabinoids. Currently, several cannabinoids may be prescribed in Canada to mitigate nausea from chemotherapy, relieve pain from cancer, prevent spasticity due to multiple sclerosis and improve appetite in patients with AIDS (Kalant et al. 2012). More recently, an increasing number of studies investigated the endogenous cannabinoid system and discovered other possible uses, including cardioprotection (Pacher et al. 2006). The therapeutic potential of cannabinoids is therefore extended; however, evidence is limited and mechanisms remain unclear. In addition, the use of cannabinoids clinically has been hindered due to pronounced psychoactive side effects, such as dizziness, euphoria and addiction (Grant et al. 2012). Clearly, the role of cannabinoids and the endocannabinoid system in cardiac function and diseases remains poorly understood. Furthermore, any attempts to develop cannabinoid-based cardiovascular therapies would require mitigation of adverse psychoactive effects. This review covers a variety of (patho)physiological effects of the endocannabinoid system, with emphasis on cannabinoid receptor subtype-specific roles in multiple disease states. 
2. Endocannabinoid system.

The endocannabinoid system is a lipid signaling system that is involved in a wide range of physiological and pathological processes such as energy metabolism and inflammation. Three major components constitute the endocannabinoid system: endocannabinoids, cannabinoid receptors, and endocannabinoid metabolism (Battista et al. 2006). Endocannabinoids are endogenously-produced bioactive lipids that activate cannabinoid receptors. Narachidonoylethanolamine (anandamide) and 2-arachidonoylglycerol (2-AG), which were initially identified in brain and intestine respectively (Devane et al. 1992; Mechoulam et al. 1995), are the best-studied naturally-occurring endocannabinoids.

Anandamide was first discovered in porcine brain (Devane et al. 1992), and was then detected in other tissues from a variety of species: bovine and rat brain, rat and human spleen, rat skin and testis of rat, as well as in the human heart (the latter, at approximately $10 \mathrm{pmol} / \mathrm{g}$ ) (Felder et al. 1996). Endogenous anandamide synthesis is a two-step process (Figure 1): i) Narachidonoyl phosphatidylethanolamine (NAPE) formation by transfer of arachidonic acid from the SN-1 position of phosphatidylcholine to the ethanolamine moiety of phosphatidylethanolamine (Sugiura et al. 1996), and ii) anandamide generation from the cleavage of NAPE by NAPE phospholipase D (Basavarajappa 2007). In fact, NAPE distribution in various regions of rat brain corresponds with that of anandamide, although NAPE concentrations are much higher (Bisogno et al. 1999). Formation of NAPE is catalyzed by Nacyltransferase (NAT). In rat cortical neurons, NAT activity is regulated by $\mathrm{Ca}^{2+}$ and cAMP (Cadas et al. 1996). An increase in intracellular $\mathrm{Ca}^{2+}$ level stimulates activity of NAT, and this activity is potentiated by a cAMP activator, such as foskolin, with subsequent cAMP-dependent protein kinase (PKA) stimulation (Cadas et al. 1996). The key role of $\mathrm{Ca}^{2+}$ in NAT activation 
was also confirmed by Cadas et al. In addition, they observed other modulators of NAT such as stimulation by dithiothreitol, and inhibition by phenylmethane sulfonyl fluoride and dithionitrobenzoic acid (Cadas et al. 1997). The second step (i.e. cleavage of NAPE) is carried out by phospholipase $\mathrm{D}$, which is activated by interaction between dopamine $\mathrm{D}_{2}$ receptors and the Rho family of small G proteins (Senogles 2000). Anandamide synthesis and release are rapid processes; for instance, anandamide synthesis and release from rat hippocampus neurons occur within $75-190 \mathrm{~ms}$ and in fewer than $50 \mathrm{~ms}$ upon stimulation at $22^{\circ} \mathrm{C}$ and $37^{\circ} \mathrm{C}$, respectively (Heinbockel et al. 2005).

2-AG was isolated from canine intestine (Mechoulam et al. 1995) and was later detected by Kondo et al. in rat brain $(3.36 \mathrm{nmol} / \mathrm{g})$, liver $(1.15 \mathrm{nmol} / \mathrm{g})$, spleen $(1.17 \mathrm{nmol} / \mathrm{g})$, kidney $(0.98$ $\mathrm{nmol} / \mathrm{g})$ and lung $(0.78 \mathrm{nmol} / \mathrm{g})$. Note that the brain contains higher concentrations (Kondo et al. 1998). Stella et al. also determined the concentration of $2-A G$ in rat brain ( $4 \mathrm{nmol} / \mathrm{g})$, and this is approximately 170 times greater than that of anandamide (23 pmol/g) (Stella et al. 1997). In fact, the amount of 2-AG is higher than anandamide in most tissues (Mechoulam et al. 1998). There are also two steps in 2-AG synthesis (Figure 1): i) diacylglycerol (DAG) is generated by phospholipid C-regulated hydrolysis of membrane phospholipids, followed by ii) DAG lipasecatalyzed conversion to 2-AG (Basavarajappa 2007). 2-AG synthesis is stimulated in response to increased intracellular $\mathrm{Ca}^{2+}$ concentration. For example, ionomycin, a $\mathrm{Ca}^{2+}$ ionophore, significantly increased 2-AG concentration in hippocampus slices (Stella et al. 1997). Additionally, others reported that 2-AG synthesis might be initiated by receptor agonism. Stella et al. found 2-AG synthesis was stimulated by $\mathrm{Ca}^{2+}$ entry through glutamate N-methyl-Daspartate (NMDA) receptor channels (Stella and Piomelli 2001), and NMDA receptor activation was reported to enhance activities of phospholipase C and DAG lipase (Stella and Piomelli 
2001). Moreover, acetylcholine receptor activation, which activates phospholipase C, increased 2-AG production in rat aorta (Mechoulam et al. 1998).

It is believed that anandamide and 2-AG are synthesized on demand upon stimulation (for example, by depolarization of postsynaptic neurons and resultant intracellular $\mathrm{Ca}^{2+}$ accumulation (Stella et al. 1997)), and released immediately due to their lipophilicity (Battista et al. 2012; Hashimotodani et al. 2013).

\subsection{Cannabinoid receptors}

\subsection{1. $\mathrm{CB} 1 / \mathrm{CB} 2$ receptors}

Two GPCRs for endocannabinoids, CB1 and CB2, have been extensively studied to date. CB1 receptors are highly expressed in brain (Matsuda et al. 1990), except in the respiratory centers of the brain stem (Howlett et al. 2002). They are particularly dense in cerebral cortex, hippocampus, basal ganglia and cerebellum. CB1 receptors are also expressed in peripheral sensory nerves and the autonomic nervous system (Quarta et al. 2010). In addition, CB1 receptors are present at measurable levels in several peripheral tissues, including the spleen, lung, thymus, heart (Bonz et al. 2003; Howlett et al. 2002) and vasculature (Gebremedhin et al. 1999; Liu et al. 2000).

In contrast, CB2 receptors are abundantly expressed in hematopoietic cells (Valk and Delwel 1998) and in the immune system (Munro et al. 1993), including spleen, tonsils, bone marrow, and leukocytes. Bouchard et al. reported that expression levels of $\mathrm{CB} 2$ receptors are comparable to that of CB1 receptors in rat hearts (Bouchard et al. 2003). It was originally believed that CB2 receptors are absent from the brain (Munro et al. 1993). However, CB2 receptor mRNA and protein expression were eventually detected in rat and mouse central nervous systems (CNS), including neurons in various regions of the brain (Skaper et al. 1996), although at a much lower level compared to CB1 receptors (Gong et al. 2006; Van Sickle et al. 
2005). CB2 receptors have since been detected in cerebrovascular endothelial cells (Golech et al. 2004), microglia (Beltramo et al. 2006) and neurons, with postsynaptic localization (Brusco et al. 2008; Callen et al. 2012; Kim and Li 2015).

Existing evidence suggests that both $\mathrm{CB} 1$ and $\mathrm{CB} 2$ receptors are coupled to $\mathrm{G}_{\mathrm{i} / \mathrm{o}}$ protein. Thus, activation of $\mathrm{CB} 1$ and $\mathrm{CB} 2$ receptors inhibits adenylyl cyclase (AC)/cAMP/PKA/ERK signaling (Demuth and Molleman 2006; Jung et al. 1997). CB1, but not CB2 receptors, also activate $\mathrm{G} \alpha_{\mathrm{s}}$ proteins, and stimulate cAMP production (McAllister and Glass 2002). These dual inhibition and activation effects of the $\mathrm{CB} 1$ receptor on AC/cAMP were demonstrated to be ligand-specific (Bonhaus et al. 1998). Furthermore, $\mathrm{CB} 1$ receptors reportedly modulate $\mathrm{Ca}^{2+}$ channels. First, activation of CB1 receptors on presynaptic neurons inhibited $\mathrm{Ca}^{2+}$ influx through N-type $\mathrm{Ca}^{2+}$ channels (Mackie et al. 1993) and hence suppressed neurotransmitter release (Shen and Thayer 1998). CB1 receptor activation also inhibited $\mathrm{Ca}^{2+}$ current through L-type $\mathrm{Ca}^{2+}$ channels in arterial smooth muscle cells leading to vasodilation (Gebremedhin et al. 1999). Second, activation of CB1 receptors stimulated $\mathrm{Ca}^{2+}$ release from internal stores in astrocytes and endothelial cells (Fimiani et al. 1999), and this was likely regulated by phospholipase C and downstream cascades. In fact, the $\mathrm{CB} 1$ receptor may couple with $\mathrm{G}_{\mathrm{q} / 11}$ and trigger the phospholipase $\mathrm{C}$ pathway (Lauckner et al. 2005). In human endothelial cells, augmented $\mathrm{Ca}^{2+}$ release via $\mathrm{CB} 1$ agonism was coupled to increased activity of nitric oxide synthase, and this may explain vasodilation induced by anandamide (Fimiani et al. 1999; Mombouli et al. 1999).

Anandamide exhibits marked selectivity for CB1 over CB2 receptors (Felder et al. 1995; Khanolkar et al. 1996), whereas 2-AG is less selective (Ben-Shabat et al. 1998; Mechoulam et al. 1995). To investigate the specific role of each receptor, analogues of endocannabinoids have been synthesized (Pertwee 2006) including, for example, the CB1-selective agonist arachidonyl- 
2-chloroethylamide (ACEA) (Hillard et al. 1999), and the CB2-selective agonist JWH-133 (Marriott and Huffman 2008). Synthetic agonists and antagonists are listed in Tables 1 and 2, respectively.

\subsubsection{Other putative cannabinoid receptors}

Some anandamide effects cannot be explained by CB1/CB2 activation, suggesting that there might exist other cannabinoid receptors (Brown and Robin Hiley 2009).

G protein-coupled receptor 55 (GPR55) has gained attention as a potential receptor for cannabinoid ligands that mediated effects independently of CB1 and CB2 receptors. In fact, it was recommended as a potential candidate as a third CB receptor (i.e. CB3) (Brown and Robin Hiley 2009). GPR55 was detected in human brain and peripheral tissues including spleen, adrenal gland and intestine (Yang et al. 2016). Although considered a potential cannabinoid receptor, GPR55 exhibits a different ligand profile from classical CB1/CB2 receptors. Ryberg et al. reported that anandamide, 2-AG, $\Delta^{9}$-tetrahydrocannabinol (THC), HU210 (CB1 agonist), and AM251 (CB1 antagonist) act as agonists of GPR55. Cannabidiol, which has a restricted affinity for $\mathrm{CB} 1$ and $\mathrm{CB} 2$ receptors, acts as an antagonist, whereas WIN55, 212-2 (CB1/CB2 agonist) and AM281 (CB1 antagonist) exert neither agonistic nor antagonistic effects (Ryberg et al. 2007). In addition, GPR55 elicits signaling cascades distinct from those of CB1/CB2 receptors. GPR55 activation stimulates the $\mathrm{G} \alpha_{12 / 13}$ pathway (Yang et al. 2016), and downstream effectors include RhoA/Rho-associated protein kinase (ROCK) and then c-Jun N-terminal kinases (JNK) and p38 MAPKs (Nishida et al. 2005), as well as PLC-induced $\mathrm{Ca}^{2+}$ release and subsequent transcriptional modification via nuclear factor of activated T-cells (NFAT) (Henstridge et al. 2009). 
Transient receptor potential vanilloid type 1 (TRPV1) receptors are non-selective cation channels that also mediate some endocannabinoid effects. Found in central and peripheral neurons (Ross 2003; Van Der Stelt and Di Marzo 2004; Zygmunt et al. 1999), as well as nonneuronal cells (Fernandes et al. 2012), they are activated by naturally-occurring vanilloids, acid and heat, and signal a painful and burning sensation. For example, myocardial ischemia causes acidification, which then activates TRPV1 and leads to angina pain (Huang et al. 2009). Anandamide and ACEA also activate TRPV1 (Ross 2003). Toth et al. summarized features of the interaction between TRPV1 and anandamide: the efficacy of anandamide on TRPV1 activation depends on tissue, species, TRPV1 expression level and phosphorylation status; the concentration of anandamide required to activate TRPV1 is higher $(\approx 10$ times $)$ than that required to activate CB1; metabolites of anandamide may activate TRPV1; activation of TRPV1 stimulates anandamide synthesis; and CB1-dependent cascades activated by anandamide (e.g. PKA or MAPKs) stimulate TRPV1 activation (Toth et al. 2009). The complex interaction between endocannabinoids and TRPV1 renders mechanisms of endocannabinoid-TRPV1 crosstalk difficult to elucidate.

In summary, $\mathrm{CB} 1$ and $\mathrm{CB} 2$ receptors are broadly distributed and are involved in a wide range of physiological processes. In addition, cannabinoid compounds also activate GPR55 and TRPV1 receptors, making them putative cannabinoid receptors. The profile of cannabinoid receptors requires further investigation.

\subsection{Endocannabinoid transport and degradation}

Endocannabinoid activity is rapidly terminated by cellular uptake and intracellular degradation. 
The transport mechanism of anandamide and 2-AG is not completely understood, although hypotheses of passive diffusion and protein transporter facilitated diffusion have been proposed (Basavarajappa 2007). Beltramo et al. identified an anandamide membrane transporter in rat neurons and astrocytes, and AM404, a competitive inhibitor of anandamide transport, prolonged and enhanced anandamide-stimulated CB1 activity (Beltramo et al. 1997). Fu et al. also discovered an anandamide-selective transport protein in rat brain and liver. It is an analogue of fatty acid amide hydrolase (FAAH), though it lacks hydrolytic activity, and is therefore named FAAH-like anandamide transporter (FLAT). A competitive FLAT inhibitor, ARN272, also generated CB1-mediated analgesic and anti-inflammation effects by suppressing the cellular uptake of anandamide (Fu et al. 2012).

Two major endocannabinoid-metabolizing enzymes are known: FAAH for anandamide and 2-AG (Deutsch and Chin 1993; Maccarrone et al. 1998), and monoacylglycerol lipase (MAGL) for 2-AG (Dinhet al. 2002; Dinh et al. 2002; Saario et al. 2004). These enzymes hydrolyze anandamide to arachidonic acid and ethanolamine, and 2-AG to arachidonic acid and glycerol, which are recycled to form phospholipids that might integrate into the cell membrane (Figure 1) (Basavarajappa 2007).

FAAH is widely expressed in many tissues, such as brain, liver, lung, spleen, testis, and kidney. Its expression was not detected in skeletal muscle and heart (Cravatt and Lichtman 2002), yet myocardial anandamide levels were elevated in FAAH knockout mice; this provides indirect evidence for the presence of FAAH in the heart (Pacher et al. 2004), perhaps at levels below detection limits. In mouse brain and liver, anandamide hydrolysis rates dropped by 100 and 50 fold respectively in FAAH knockout mice (Cravatt et al. 2001). Regulation of FAAH activity has been considered an important approach to manipulate the endocannabinoid system. To date, little 
evidence of a receptor-dependent regulatory mechanism exists, but many efforts have been made toward synthesis of chemical stimulators and inhibitors of FAAH (Faure et al. 2014; Lodola et al. 2015).

MAGL mRNA was also detected in a number of rat tissues, including adipose tissue, kidney, brain, heart, lung, liver, skeletal muscle and spleen (Karlsson et al. 1997). Blankman et al. reported that MAGL contributes to $85 \%$ of $2-\mathrm{AG}$ hydrolysis in mouse brain, whereas FAAH only accounts for $1 \%$ (Blankman et al. 2007). MAGL is reportedly upregulated by peroxisome proliferator-activated receptor $\alpha(\operatorname{PPAR} \alpha)$, at least at the transcriptional level in mouse hepatocytes (Rakhshandehroo et al. 2007).

Other enzymes in addition to FAAH and MAGL reportedly degrade anandamide and 2-AG, but their activity is less clear compare to that of MAGL and FAAH (Basavarajappa 2007; Pertwee 2014). These include FAAH-2, N-acylethanolamine-hydrolyzing acid amidase (NAAA), $\alpha / \beta$ hydrolase domain (ABHD), cyclooxygenase-2 (COX-2), and cytochrome $\mathrm{p} 450$. FAAH-2 was identified in primate models, including humans, but not in rodents. However, its hydrolytic activity for anandamide is approximately 38 times lower than FAAH (Wei et al. 2006). NAAA was also identified in various human, rat, and mouse tissues (eg. lung, spleen and small intestine). Using N-palmitoylethanolamine, an anandamide analogue, as reference, rat FAAH catalytic activity shows a preference towards anandamide $\left(\mathrm{V}_{\max }=5700 \mathrm{nmol} / \mathrm{min} / \mathrm{mg} ; \mathrm{K}_{\mathrm{m}}=30 \mu \mathrm{M}\right)$ over Npalmitoylethanolamine $\left(\mathrm{V}_{\max }=1800 \mathrm{nmol} / \mathrm{min} / \mathrm{mg} ; \mathrm{K}_{\mathrm{m}}=70 \mu \mathrm{M}\right)$ (Katayama et al. 1999), whereas rat NAAA hydrolase activity for anandamide was only $8 \%$ of that for N-palmitoylethanolamine $\left(\mathrm{V}_{\max }=1847 \mathrm{nmol} / \mathrm{min} / \mathrm{mg} ; \mathrm{K}_{\mathrm{m}}=35 \mu \mathrm{M}\right)$ (Ueda et al. 2001), suggesting that NAAA exerts weak hydrolase activity for anandamide compared to FAAH. Furthermore, NAAA exhibits no hydrolase activity on 2-AG (Ueda et al. 2001). Thus, it is reasonable to conclude that the role of 
NAAA as a hydrolase of endocannabinoids is insignificant.

Proteins that contain the ABHD (i.e. ABHD 6 and ABHD 12) are serine hydrolases that can hydrolyze 2-AG. In fact, ABHD 6 and ABHD 12 account for 4\% and 9\% of total 2-AG hydrolysis in mouse brain, respectively (Blankman et al. 2007). COX-2 is well known for its ability to convert arachidonic acid to the pro-inflammatory lipid, prostaglandin. COX-2 also oxygenates anandamide and 2-AG to produce ethanolamide and glycerol ester derivatives of prostaglandin respectively (Rouzer and Marnett 2011). Likewise, various families of cytochrome p450 (e.g. 3A4, 4F2, and 2D6) oxidize anandamide into different isoforms of epoxyeicosatrienoic acids ethanolamides (EET-EAs) and hydroxy-eicosatetraenoic acids ethanolamides (HETE-EAs), which exhibit diverse effects on inflammation and vascular tone (Rouzer and Marnett 2011). Cytochrome p450 was only recently implicated in 2-AG oxidation in 2014, when McDougle et al. detected 2-AG metabolite production (i.e. 2-EET-glycerols) by CYP2J2, a predominant cytochrome p450 in the heart. CYP2J2 also hydrolyzes 2-AG to glycerol and arachidonic acids in a NADPH-dependent manner (McDougle et al. 2014). Reports of COX2- and cytochrome p450-dependent metabolism of endocannabinoids have only recently emerged and represent novel research areas that warrant further investigation.

The aforementioned enzymes responsible for degrading endocannabinoids play an important role in terminating endocannabinoid signaling. Indeed, manipulating the levels of FAAH and MAGL by overexpression, knockdown or using their inhibitors has been an area of intense study. For example, Hohmann et al. reported that inhibition of MAGL and FAAH increased 2-AG and anandamide levels in rat brain and enhanced anti-hyperalgesic effects (Hohmann et al. 2005). Ho et al. found that FAAH and MAGL inhibitors enhanced the vasodilatory actions of anandamide and 2-AG in rat isolated small mesenteric arteries (Ho and 
Randall 2007). Carnevali et al. demonstrated an anti-depressant effect of FAAH inhibition, which was associated with increases in central and peripheral anandamide levels (Carnevali et al. 2015).

Collectively, endocannabinoid signaling includes endocannabinoid biosynthesis, receptor activation, membrane transport and degradation. Each of these represents a potential therapeutic target by which the endocannabinoid system might be manipulated.

3. (Patho-)physiological functions of the endocannabinoid system

Cannabis sativa, which stimulated interest in the endocannabinoid system, contains more than 60 phytocannabinoids. Among them, THC and cannabidiol are considered the major components (Szaflarski and Bebin 2014). THC mainly activates CB1 receptors, which are abundantly expressed in central nervous system, and accounts for the psychoactive effects of cannabis use (Pertwee 2008). It is now widely accepted that THC activates CB1 receptors located on presynaptic terminals, and this leads to inhibition of neurotransmitter release. Conversely, activated CB1 may stimulate release of neurotransmitters such as dopamine, from other neurons. These dual inhibitory and stimulatory actions of THC on neurotransmitter release might provide an explanation for the complex mood effects (for example, euphoria vs. anxiety) that might be observed after cannabis use (Pertwee 2008). Cannabidiol, in contrast, lacks psychoactivity. It exhibits low affinities for both $\mathrm{CB} 1$ and $\mathrm{CB} 2$ receptors, and may in fact act instead as an inverse agonist of CB1 receptors (Thomas et al. 2007). Consistent with this notion, cannabidiol prevented THC-induced psychotic responses in humans (Bhattacharyya et al. 2010). Finally, $C$. sativa has also been used to relieve nausea and diarrhea.

Considering the physiological processes influenced by $C$. sativa, as well as the wide distribution of endocannabinoids and their receptors throughout the body, the endocannabinoid 
system has been implicated in multiple physiological and pathological processes. Whether acting at $\mathrm{CB}$ receptor or non- $\mathrm{CB}$ receptor sites, cannabinoid-related compounds exert inhibitory effects on obesity, inflammation, pain, and chemotherapy-induced nausea or vomiting, and may alleviate the symptoms of neurodegenerative diseases and multiple sclerosis. Nabilone, dronabinol, and sativex are cannabinoid-based drugs that have been approved to treat pain, appetite loss, spasticity and chemotherapy-induced nausea (Grant et al. 2012). However, it should be noted that cannabinoids are linked to undesirable side effects, particularly psychoactive in nature. Therefore, the endocannabinoid system is a convergence of benefits and risks that requires careful and comprehensive study.

\subsection{Appetite and energy expenditure}

Central CB1 receptors play an important role in appetite regulation. Kirkham et al. found that injection of 2-AG to limbic forebrain, a brain area that controls eating motivation, stimulated appetite, and this was inhibited by rimonabant (SR141716), an CB1 antagonist (Kirkham et al. 2002). Appetite stimulation by CB1 receptors was confirmed by Cota et al., who observed reductions in food intake and body weight in CB1-deficient mice (Cota et al. 2003). In contrast, FAAH-deficient mice exhibited enhanced appetite and this was accompanied by elevated anandamide levels in hypothalamus, liver, and small intestine (Tourino et al. 2010). The stimulatory effect on appetite corresponds with the finding that anandamide and 2-AG levels in limbic forebrain and hypothalamus were highest during fasting, but dropped during eating (Kirkham et al. 2002). A clinical trial on dronabinol, a cannabinoid-based drug, showed improved appetite in AIDS patients, and dronabinol was subsequently approved to treat AIDSassociated anorexia (Beal et al. 1995).

In addition to appetite regulation, $\mathrm{CB} 1$ receptors also modulate energy expenditure. Verty 
et al. reported that $\mathrm{CB} 1$ blockade with rimonabant in rats enhanced thermogenesis in brown adipose tissue, and this was associated with up-regulation of UCP1, a protein that stimulates heat production. These changes were partially attenuated by denervation, implying the role of central CB1 receptors in restricting energy expenditure (Verty et al. 2009). A clinical trial that involved obese patients with hypertension or dyslipidemia showed that rimonabant ( $20 \mathrm{mg} / \mathrm{day})$ reduced body weight and waist circumference, and also improved several cardiovascular metabolic parameters (i.e. increased high-density lipoprotein and decreased triglycerides and insulin resistance) (Van Gaal et al. 2005). These findings were in agreement with similar clinical trials on rimonabant (Pi-Sunyer et al. 2006; Scheen et al. 2006). In 2006, rimonabant was released into the European market as an anti-obesity drug, although it was quickly withdrawn due to reports of adverse effects such as nausea, depression and anxiety (Di Marzo and Despres 2009).

To eliminate the psychiatric effects mediated by central CB1 receptors, attempts were made to evaluate the contribution of peripheral $\mathrm{CB} 1$ receptors to obesity. Cluny et al. observed a transient reduction in food intake and sustained body weight loss in response to a peripherallyrestricted CB1 receptor antagonist, AM6545, in rats and mice (Cluny et al. 2010). Reduced hepatic triglycerides, increased expression of fatty acid oxidation genes, and improved insulin sensitivity were also confirmed with AM6545 (Tam et al. 2010). Hsiao et al. compared the effects of rimonabant and BPR0912, a peripherally-restricted CB1 receptor antagonist, on obesity parameters in diet-induced obese mice. Similar reductions in body weight, serum insulin, triglycerides, and hepatic triglycerides were observed with both compounds, but compared to rimonabant, BPR0912 raised fatty acid oxidation-related gene expression and thermogenesis more significantly (Hsiao et al. 2015). In summary, activation of CB1 receptors contributes to increased appetite, suppressed energy expenditure, and when deranged, obesity. Therefore, 
antagonism of CB1 receptors, particularly in the periphery, remains a promising approach to enhance adipocyte lipolysis, reduce food intake and decrease body weight (Arrabal et al. 2015; Mastinu et al. 2012).

The role of CB2 receptors in food intake and energy metabolism is not as extensively studied as that of CB1, but appears to oppose CB1 effects. The observation that the inhibitory effect of AM6545 on food intake was abolished in CB1/CB2 knockout mice, but not in CB1 knockout mice indicated that CB2 receptors might be involved (Cluny et al. 2010). Onaivi et al. reported increased appetite in $\mathrm{C} 57 \mathrm{~B} 1 / 6$ mice treated with the $\mathrm{CB} 2$ receptor antagonist $\mathrm{AM} 630$ after $12 \mathrm{~h}$ food-deprivation, but not in other strains (i.e. Balb/c and DBA/2) (Onaivi et al. 2008). Similarly, the CB2 receptor agonist JWH015 induced a transient reduction in food intake in C57B1/6 mice, which was restored by AM630. JWH-015 also induced body weight loss, reduced white adipose tissue weight and adipocyte cell size, and increased triglyceride lipase expression (Verty et al. 2015).

\subsection{Inflammation}

As CB2 receptors are abundantly expressed in the immune system (Munro et al. 1993), the involvement of CB2 receptors in inflammation is well-documented. Indeed, CB2 receptors play an important role in preventing gastrointestinal inflammation. Storr et al. reported that the CB2 receptor agonists, JWH133 and AM1241, attenuated colitis in mice, and pretreatment with a CB2 receptor antagonist or CB2 knockout abrogated this effect (M. Storr et al. 2009). Similar findings were observed in human colonic mucosa, where tumor necrosis factor- $\alpha$ (TNF- $\alpha)$ and interleukin-1 $\beta$ (IL-1 $\beta$ )-induced inflammation, as evidenced by luminal epithelial and crypt damage and increased lymphocyte density, was attenuated by CB2 activation (Harvey et al. 2013). Overexpression of CB2 receptors in intestine was detected in models of inflammatory 
bowel disease, suggesting the important role of CB2 receptors as a compensatory antiinflammatory response (M. Storr et al. 2009; Wright et al. 2005).

Anti-inflammatory actions of CB2 receptors were also observed in other tissue or cells. For example, anandamide and 2-AG alleviated inflammation in cultured human retinal explant, which was reflected by increased viability of retinal neurons and Muller glia, as well as reduced Muller glia proliferation. This anti-inflammatory effect was achieved by inhibiting proinflammatory cytokines (e.g. IL-6, interferon- $\gamma($ IFN- $\gamma$ ), and TNF- $\alpha$ ) while elevating antiinflammatory molecules (e.g. IL-10 and transforming growth factor- $\beta$ (TGF- $\beta$ )) (Krishnan and Chatterjee 2012). CB2 receptor activation also relieved rheumatoid arthritis symptoms via multiple pathways, including inhibition of fibroblast proliferation, suppression of proinflammatory cytokine release in fibroblast-like synoviocytes, $\mathrm{T}$ cells and macrophages, as well as prevention of bone erosion via stimulating osteoblasts and reducing osteoclasts (Gui et al. 2015).

Incidentally, the anti-inflammatory properties of cannabinoids are also an important aspect of treating neurodegenerative diseases, and cardiovascular risk factors, where inflammation is a key factor. This is discussed below.

\subsection{Cancer}

CB1 and CB2 receptors have been detected in a variety of cancer cell lines, including astrocytoma (Sanchez et al. 2001), breast cancer (Caffarel et al. 2010), prostate cancer (Chung et al. 2009), lung cancer (Preet et al. 2008) and so on. Greater content of CB1 or CB2 is also associated with increased tumor malignancy (Chung et al. 2009; Gustafsson et al. 2011; Orellana-Serradell et al. 2015; Sanchez et al. 2001). 
Cannabinoids may prevent or ameliorate cancer development first by inhibiting tumor growth. Numerous studies observed apoptosis-inducing effects of cannabinoids and their synthetic analogues in a variety of cancer types. For example, THC and WIN-55, 212-2 inhibited the progression of malignant gliomas in rats and mice by inducing apoptotic signaling; possible mechanisms include cannabinoid receptor-activated ceramide accumulation and Raf1/ERK1/2 activation (Galve-Roperh et al. 2000). Selective activation of CB2 receptors also triggered apoptosis within glioma by increasing ceramide synthesis (Sanchez et al. 2001). Moreover, combining a cannabinoid, either THC or cannabidiol, with temozolomide (TMZ), a conventional glioma therapy, significantly enhanced antitumor action in a mouse glioma model, as evidenced by reduced tumor volume compared to TMZ alone (Torres et al. 2011). The role of CB1 receptors in stimulating apoptosis was validated in breast cancer and prostate cancer cultures (primary and commercial cell lines) (De Petrocellis et al. 1998; Orellana-Serradell et al. 2015). Molecular signaling involves ERK activation and Akt inhibition (Orellana-Serradell et al. 2015). Akt inhibition pathway was confirmed further in an in vivo study, in which THC and JWH-133, by activating CB2 receptors, suppressed breast tumor growth and lung metastases in a mouse model of malignant breast cancer (Caffarel et al. 2010). Furthermore, in vitro and in vivo studies reported that both $\mathrm{CB} 1$ and $\mathrm{CB} 2$ are involved in anti-tumor actions in colon cancer, and TNF- $\alpha$ contributes to $\mathrm{CB} 1 / \mathrm{CB} 2-$ mediated apoptosis by increasing ceramide production and caspase 3 apoptotic signaling (Cianchi et al. 2008).

Metastasis may also be mitigated by cannabinoids. Met-F-AEA, a metabolically stable analogue of anandamide, suppressed the adhesion and migration of a human breast cancer cell line, and these actions were attributable to CB1-mediated inhibition of focal adhesion kinase (FAK) (Grimaldi et al. 2006). Suppression of the RhoA-ROCK pathway also contributes to the 
ability of CB1 to inhibit human breast and prostate cancer cell invasion and migration (Laezza et al. 2008; Nithipatikom et al. 2012). Similar findings were reported in lung cancer cell lines, where THC significantly reduced cell migration, and this was accompanied with inhibition of epidermal growth factor (EGF), FAK, ERK1/2, JNK1/2, and AKT (Preet et al. 2008). Finally, Hinz et al. reported that activation of CB1 and CB2 enhanced expression of tissue inhibitors of matrix metalloproteinases (TIMP-1) in cervical cancer cells which would reduce extracellular matrix degradation, and thereby attenuate metastasis.

\subsection{Emesis}

Emesis can be triggered centrally or peripherally. Stimuli such as food toxins and chemotherapeutic agents evoke vomiting primarily by inducing serotonin $(5-\mathrm{HT})$ release from the epithelium of the gastrointestinal tract. By activating 5-HT receptors in afferent nerves, signals are communicated to the emesis center in the medulla, followed by a series of motor responses. This emesis center can also be directly activated by central stimuli, for instance, aversive memories (Becker 2010). Cannabinoids have traditionally been used to treat nausea and vomiting. Nabilone and dronabinol, synthetic analogues of THC, are approved to treat chemotherapy-induced vomiting (Sharkey et al. 2014). A clinical trial compared dronabinol, ondansetron (5-HT antagonist), and their combination on chemotherapy-induced nausea and emesis, and found similar anti-emetic effects, However, dronabinol alone showed a better effect on reducing the severity of nausea (Meiri et al. 2007). Sativex, a 1:1 combination of THC and cannabidiol, is not yet approved to treat chemotherapy-induced vomiting. However, a clinical trial observed that in combination with standard anti-emetic therapy, sativex improved chemotherapy-induced nausea and vomiting compared to standard therapy alone (Duran et al. 2010). The role of the endocannabinoid system in anti-emetic effects was investigated in animal 
models. Hu et al. showed that CB1 receptor activation inhibited enterotoxin-induced 5-HT release from the intestine of musk shrew, suggesting a peripheral action of CB1 in the antiemetic effect of cannabinoids (Hu et al. 2007). The role of CB1 receptors was confirmed by other studies (Darmani 2001; O'Brien et al. 2013), but evidence on CB2 receptors is lacking.

\subsection{Pain}

Pain is regulated by the endocannabinoid system at both central and peripheral sites. Following electrical stimulation, Walker et al. detected release of anandamide in periaqueductal gray, the primary brain region for pain modulation, which coincided with the central CB1mediated analgesic effect (Walker et al. 1999). Clapper et al. reported that URB937, a peripheral FAAH inhibitor, generated a peripheral accumulation of anandamide, and suppressed both neuropathic and inflammatory pain-related behavior responses as well as neuron activation in the spinal cord; a CB1 receptor antagonist reversed these effects. The ability of URB937 to modulate pain signals despite its lack of CNS penetration implies that activation of peripheral CB1 receptors exhibits an analgesic effect by blocking the transduction of pain signals into the CNS (Clapper et al. 2010). The CB2 receptor was originally found to suppress pain sensation by attenuating the release of pro-inflammatory molecules which increase the sensitivity of primary afferent neurons (Malan et al. 2003). Beltramo et al. later observed a direct inhibition of pain neurotransmitter production by $\mathrm{CB} 2$ receptors as well, in parallel to its analgesic effects in a rat model of neuropathic pain and a mouse model of central sensitization (Beltramo et al. 2006). Finally, Romero et al. confirmed the analgesic actions of CB1 and CB2 receptors, in a manner that requires activation of peripheral adrenergic receptors by norepinephrine (Romero et al. 2013). 


\subsection{Endocannabinoid signaling in the CNS}

The endocannabinoid system has been extensively studied in the brain. Anandamide is found in brains of animal models at concentrations of $173 \mathrm{pmol} / \mathrm{g}, 101 \mathrm{pmol} / \mathrm{g}$ and $30 \mathrm{pmol} / \mathrm{g}$ in porcine, bovine and rat brain, respectively (Bisogno et al. 1999; Schmid et al. 1995). Felder et al. measured anandamide concentrations in specific regions of human brain, and identified a range of approximately $35 \mathrm{pmol} / \mathrm{g}$ in cerebellum to $107 \mathrm{pmol} / \mathrm{g}$ in hippocampus (Felder et al. 1996). A brief overview on the important role of endocannabinoid signaling in a few CNS disorders is discussed below.

\subsubsection{Multiple sclerosis}

Multiple sclerosis is an autoimmune disorder characterized by axon demyelination of neurons within CNS. Cannabis has traditionally been used to relieve symptoms, and current thinking attributes the beneficial effects to immunosuppressive and neuroprotective properties of cannabinoid receptors. However, whether cannabinoid ligands delay multiple sclerosis progression remains unknown, though preclinical studies are supportive. For example, microglial cells, which are the primary immune cells in the CNS, can be activated to secrete proinflammatory factors, including IL-12 and IL-23, thereby contributing to the progression of multiple sclerosis. Anandamide inhibited secretion of IL-12 and IL-23 in microglial cells, at least in part through a CB2-dependent ERK1/2 and JNK pathway (Correa et al. 2009). An increase in anandamide concentration was detected in inflammatory brain tissue from multiple sclerosis patients (Eljaschewitsch et al. 2006). Furthermore, in experimental autoimmune encephalomyelitis mice, a model of multiple sclerosis, WIN55, 212-2 (CB1/CB2 agonist) attenuated the up-regulation of inflammatory cytokines (COX-2, iNOS and TNF- $\alpha$ ) and microglial-induced cell aggregation in spinal cord and brainstem. These effects of WIN55, 212-2 
were reversed by a CB1 receptor antagonist (de Lago et al. 2012). Increasing 2-AG levels in mice spinal cord using a MAGL inhibitor also slowed the progression of multiple sclerosis, and was associated with decreased leukocyte infiltration and microglial activity (Hernandez-Torres et al. 2014). However, the Cannabinoid Use in Progressive Inflammatory brain Disease (CUPID) trial failed to show benefits of dronabinol on multiple sclerosis progression, perhaps due to slow progression rate which confounded statistical detection of group differences (Zajicek et al. 2013).

\subsubsection{Neurodegenerative diseases}

Parkinson's disease, Huntington's disease, and Alzheimer's disease are three common neurodegenerative diseases characterized by progressive degeneration and/or death of neurons. No therapy has been discovered to cure these diseases yet. However, manipulation of the endocannabinoid system has shown promising effects towards alleviating symptoms.

\subsubsection{Parkinson's disease}

Price et al. showed that administration of WIN55, 212-2 improved survival of dopamineproducing neurons in a mouse model of Parkinson's disease (i.e. 1-methyl-4-phenyl-1, 2, 3, 6tetrahydropyridine-induced), in parallel with improved motor performance. This was mediated by CB2 receptors, whose expression was increased in the disease model (Price et al. 2009). Similar findings were observed in a lipopolysaccharide-induced mouse model of Parkinson's disease (Garcia et al. 2011). Unlike the beneficial effects of CB2 receptor activation, $\mathrm{CB} 1$ contributed to disease progression. Rimonabant, a CB1 antagonist, improved motor coordination, but did not alter neurodegeneration (Gonzalez et al. 2006; Kelsey et al. 2009). In addition, neuroprotection provided by some cannabinoid agents such as THC, cannabidiol, and AM404, is due to antioxidant actions (Garcia-Arencibia et al. 2007). For example, cannabidiol, a naturallyoccurring cannabinoid with limited affinity for $\mathrm{CB} 1$ and $\mathrm{CB} 2$ receptors, attenuated dopamine 
reduction and increased SOD expression (Garcia-Arencibia et al. 2007). In addition, two anandamide uptake inhibitors, AM404 and UCM707, which would increase anandamide levels, were compared. AM404, which possesses antioxidant properties, rescued dopamine levels in a rat model of Parkinson's disease, whereas UCM707, which lacks antioxidant properties, did not (Garcia-Arencibia et al. 2007). In summary, agonism of CB2 receptors, antagonism of CB1 receptors, and cannabinoids that exert antioxidant activity might improve symptoms of Parkinson's disease.

\subsubsection{Huntington's disease}

Huntington's disease is a genetic neurodegenerative disease that is characterized by impaired muscle coordination and cognitive ability, as well as behavior changes, such as anxiety, depression, apathy and aggression. It is caused by a mutation of the Huntington gene, which leads to neuron degeneration mainly in the striatum. No treatment is known to slow disease progression. Cannabinoid compounds may exert symptom-relieving effects. The malonateinduced rat model of Huntington's disease is associated with increased proinflammatory molecules, edema, and microglial activity. A combination of THC and cannabidiol reversed all of these in a CB1 - and CB2-dependent manner (Valdeolivas et al. 2012). The role of CB2 receptors was confirmed in $\mathrm{CB} 2$ knockout mice, which responded more severely to malonate (Sagredo et al. 2009). CB1 receptor activity declines dramatically in basal ganglia and striatum during the progression of Huntington's disease, and this decline was proposed as a contributor to disease progression. However, markedly reduced $\mathrm{CB} 1$ levels render the $\mathrm{CB} 1$ receptor a poor therapeutic target (Lastres-Becker et al. 2001), although cannabinoid treatments (anandamide, methanandamide, and ACEA) increase CB1 mRNA in mouse striatal progenitor cell lines that model features of Huntington's disease (Laprairie et al. 2013). A double-blind, placebo- 
controlled, cross-over clinical trial involving 44 patients with Huntington's disease showed that while nabilone failed to improve motor score, the chorea score was improved significantly (Curtis et al. 2009).

\subsubsection{Alzheimer's disease}

Alzheimer's disease is characterized by the excessive deposition of $\beta$-amyloid peptide and activation of microglial cells in senile plaques, which lead to neuron degeneration mainly in the hippocampus and prefrontal cortex. Symptoms include cognitive impairment, memory loss, mood swings, behavior changes and so on. Both $\mathrm{CB} 1$ and $\mathrm{CB} 2$ receptors were detected in senile plaques (Ramirez et al. 2005). CB2 receptor agonism attenuated $\beta$-amyloid-induced microglia activation and microglia-induced neurotoxicity in rats, and it preserved cognitive ability (Ramirez et al. 2005). However, studies on CB1 receptors in the progression of Alzheimer's disease are controversial. Some found CB1 is detrimental to memory and learning ability, fostering interest in CB1 antagonism as a treatment approach. For example, Mazzola et al. reported that the $\mathrm{CB} 1$ antagonist, rimonabant, reversed $\beta$-amyloid peptide-induced memory deficit in mice (Mazzola et al. 2003). In contrast, others demonstrated beneficial effects of CB1 receptors. First, CB1 levels are markedly reduced in brains of various animal models with Alzheimer's disease (Aso et al. 2012; Ramirez et al. 2005). Also, in patients, CB1 activity is increased in the earlier stage of Alzheimer's disease, followed by a reduction in advanced stages of the disease. This implies an initial compensatory response mediated by CB1, which was impaired as neurodegeneration developed (Manuel et al. 2014). Second, Aso et al. showed that the $\mathrm{CB} 1$ agonist ACEA, at a non-amnesic dose, prevented cognitive retardation in a mouse model of Alzheimer's disease, particularly in the early stage. Mechanisms include inhibition of

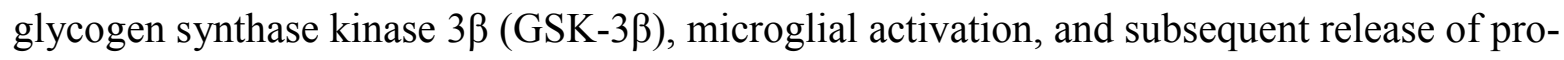


inflammatory factors (Aso et al. 2012). There is little evidence derived from clinical trials to support the use of cannabinoid-based compounds to treat Alzheimer's disease. However, dronabinol improved adverse psychiatric effects such as agitation, insomnia, and appetite loss in a few small clinical trials (Ahmed et al. 2015).

\subsubsection{Mood}

It is well known that marijuana use elicits a feeling described as "high." In fact, this is a complex of psychoactive effects due mainly to THC and cannabidiol, the major cannabinoids in marijuana (Fitzgerald et al. 2013). Thus, it was speculated that the endocannabinoid system mediates anti-depressant and anxiolytic effects. The role of CB1 receptors is well-established. The anti-depressant properties of low dose WIN55, 212-2 in rat were blocked by a CB1 receptor antagonist (Bambico et al. 2007). Injection of anandamide and a CB1 selective agonist, ACEA, into midbrain dorsolateral periaqueductal gray, a region that regulates anxiety responses, also elicited anxiolytic effects in rats, whereas a CB1 antagonist abolished these effects (Moreira et al. 2007). However, in these two studies, high doses of cannabinoids failed to elicit the same effects. In fact, evidence suggests that the effects of cannabinoids on anxiety are bidirectional; anxiolytic at low doses whereas anxiogenic at high doses (Rubino et al. 2008; Viveros et al. 2005). In addition, Rubino et al. found that the anxiety-regulation profile of cannabinoids varies in different brain regions. For example, low and high doses of THC injected into the prefrontal cortex and ventral hippocampus elicit anxiolytic and anxiogenic effects, respectively; however, low doses of THC in basolateral amygdala generate anxiogenic effects whereas high doses of THC were ineffective (Rubino et al. 2008).

Despite the complex activity profile of cannabinoids on anxiety and depression, it is consensus thinking that disruption of CB1 signaling leads to depressive- and anxiogenic-like 
responses (Moreira et al. 2009). Also, activation of CB1 receptors contributes to the removal of aversive memories (Marsicano et al. 2002). Therefore, CB1 inhibition causes retention of aversive memories and may exacerbate depressive feelings. Patients treated with rimonabant, a CB1 antagonist, as an anti-obesity drug, exhibited depression and anxiety symptoms, and even increased risk of suicide, leading to withdrawal from the market (Christensen et al. 2007).

In summary, both suppression and hyperactivity of the endocannabinoid system may elicit adverse effects, such as anxiety and depression. These effects are mediated by CB1 receptors in the CNS, which should be considered during drug development.

\subsubsection{Sleep}

Cannabis use has long been associated with improved sleep, and a variety of cannabinoids, either naturally-occurring or synthetic compounds, promote sleep. For example, elevation of anandamide levels, achieved by blocking hydrolysis or direct injection, prolonged sleep duration by increasing non-rapid eye movement (NREM) sleep and rapid eye movement (REM) cycles, and this was interrupted by a CB1 antagonist (Mendez-Diaz et al. 2013; Murillo-Rodriguez et al. 2008). Similarly, administration of CP47, a CB1 agonist, or inhibition of endocannabinoid degradation, stabilized NREM sleep as evidenced by increased NREM bout duration. In contrast, the CB1 antagonist AM281 fragmented NREM without reducing overall sleep time. Rimonabant, also a CB1 antagonist, disturbed REM sleep in rats (Santucci et al. 1996), and CB1 knockout mice exhibited reduced non-rapid eye movement (NREM) sleep (Pava et al. 2014). In fact, rimonabant was withdrawn as an anti-obesity drug due to severe psychoactive side effects, among which insomnia is very common (Nathan et al. 2011). Mechanisms underlying CB1dependent sleep promotion is largely unknown, though elevated adenosine (Murillo-Rodriguez et al. 2003) and c-Fos expression (Murillo-Rodriguez et al. 2008) might be involved. Collectively, 
these findings demonstrated the role of CB1 in maintenance of NREM sleep stability (Pava et al. 2016).

Clinical studies were conducted to evaluate the effects of medical cannabinoids on sleep quality of patients with neuropathic pain, multiple sclerosis, and cancer. While there is reportedly risk of bias in some studies, including non-validated measurements of sleep and failure to blind participants to their treatments, there are reports of positive outcomes such as improved sleep quality, fewer nightmares, reduced sleep interference, etc. (Gates et al. 2014).

\subsection{Endocannabinoid system and the cardiovascular system}

Components of the endocannabinoid system are elevated in various aspects of cardiovascular disease, including atherosclerosis, myocardial infarction and cardiac hypertrophy (Duerr et al. 2013; Lin et al. 2015). The following sections discuss the potential roles of endocannabinoids and their receptors in regulation of cardiovascular health.

\subsubsection{Hemodynamic parameters}

Marijuana use leads to blood pressure changes, and the influence of endocannabinoids on hemodynamics has been extensively studied. However, the results are complex. THC induced biphasic changes in blood pressure and heart rate in anesthetized rats, which were characterized by an immediate and transient blood pressure increase followed by a marked drop and prolonged hypotension and bradycardia (Lake et al. 1997). Intravenous injection of anandamide caused a three-phase hemodynamic change in anesthetized rats, including i) phase 1 - a transient reduction in blood pressure, heart rate and cardiac contractility, ii) phase 2 - an elevation of diastolic blood pressure and blood flow in mesenteric and renal vascular beds, followed by iii) phase 3 - a more prolonged and significant decrease in blood pressure and contractility, and a slight reduction in heart rate (Malinowska et al. 2001; Pacher et al. 2004). Other synthetic 
compounds, such as HU210, WIN55, 212-2, and CP-55940, also induced prolonged hypotension and bradycardia, although without the initial phases that were observed with THC and anandamide (Lake et al. 1997).

Possible mechanisms include CB1 or CB2 receptor activation, TRPV1 activation and metabolite-induced pathways. A similar three-phase action was observed with methanandamide, a stable analogue of anandamide, indicating the involvement of cannabinoid receptors. In addition, the CB1 receptor antagonist, rimonabant, blocked the phase 3 response, but not the transient pressor effect of THC nor the first two phases of anandamide. This suggests that CB1 is responsible for the prolonged hypotension and bradycardia (Lake et al. 1997; Malinowska et al. 2001), perhaps by suppressing the sympathetic nervous system (Niederhoffer et al. 2001). In contrast, a TRPV1-selective antagonist diminished the phase 1 responses induced by anandamide and methanandamide, suggesting that TRPV1 mediates the initial transient drop of blood pressure and heart rate (Malinowska et al. 2001). Phase 2 may also be induced by TRPV1 receptors, as evidenced by the observation that capsaicin, a potent TRPV1 agonist, also generated the phase 2 increase in blood pressure in anesthetized rats, and this increase was absent in TRPV1 knockout mice compared with wild-type mice (Pacher et al. 2004).

It bears mentioning that the influence of cannabinoids on hemodynamic parameters is different in conscious animals. Unlike the three-phase changes described in anesthetized rats, anandamide elicited the first two phases (i.e. transient depressor and pressor responses) in conscious rats, but not the prolonged hypotension and bradycardia (Lake et al. 1997). This might be explained by the anesthetic agent, urethane, which attenuated the sympathetic suppression of CB1 (Kurz et al. 2009), or the relatively high resting sympathetic tone in anesthetized animals, which renders the hypotensive action of cannabinoids more evident (Carruba et al. 1987). 
In humans, marijuana use and cannabinoid agents (sativex and nabilone) were associated with an acute acceleration of heart rate that usually peaks at 10 to $30 \mathrm{~min}$ after smoking (Karschner et al. 2011; Lile et al. 2011). This is regarded as an important biomarker of cannabinoid use (Zuurman et al. 2009). The CB1 antagonist rimonabant ameliorated the tachycardia caused by cannabis use (Huestis et al. 2007). Marijuana use also caused hypotension and dizziness in standing position (Mathew et al. 2003), which was attenuated by rimonabant (Gorelick et al. 2006). An in vitro study demonstrated that CB1 receptor activation by anandamide dilates human vessels by stimulating endothelial nitric oxide release (Bilfinger et al. 1998).

\subsubsection{Atherosclerosis}

Manipulation of cannabinoid receptors $(\mathrm{CB} 2$ receptor activation and $\mathrm{CB} 1$ receptor inhibition) might also limit atherosclerotic progression, as suggested by animal studies. The antiatherosclerotic effects of $\mathrm{CB} 2$ receptors might be due, at least in part, to its anti-inflammatory actions. Steffens et al. detected CB2 expression in atherosclerotic plaques within human coronary arteries and mouse aorta, but not in regions free of atherosclerotic lesions. They also reported that THC, at a non-psychiatric dose, ameliorated the progression of atherosclerosis, reduced macrophage content and migration within atherosclerotic plaques, and suppressed $\mathrm{T}$ cell activation in apolipoprotein E-deficient mice, a common model of atherosclerosis. A CB2 receptor antagonist blocked all of these effects, indicating the protective role of CB2 receptors (Steffens et al. 2005). Similar effects were reported with WIN55, 212-2, which reduced atherosclerotic size, macrophage infiltration, adhesion molecule expression (i.e. vascular cellular adhesion molecule-1, intracellular adhesion molecule-1, and P-selectin), and expression of proinflammatory mediators (i.e. TNF- $\alpha$, IL-6, and monocyte chemotactic protein 1 ) in a CB2- 
dependent manner (Zhao et al. 2010; Zhao et al. 2010). Also, it attenuated oxidized low-density lipoprotein (oxLDL)-induced activation of nuclear factor $\kappa$-light-chain-enhancer of activated B cells $(\mathrm{NF}-\kappa \mathrm{B})$, which in turn up-regulates pro-inflammatory factors (Zhao et al. 2010). In addition, CB2 receptor activation reversed TNF- $\alpha$-induced proliferation of human coronary artery smooth muscle cells and the underlying MAPK pathway (Rajesh et al. 2008).

In contrast, evidence suggests that $\mathrm{CB} 1$ signaling contributes to the atherosclerotic process. First, CB1 antagonism reduced cholesterol deposition in macrophages. Jiang et al. reported suppression of PPAR $\gamma$ by the CB1 antagonist, AM251; PPAR $\gamma$ up-regulates fatty acid translocase/CD36 receptor, which mediates macrophage cholesterol influx, and down-regulates ATP-binding cassette protein A1, which mediates cholesterol efflux (Jiang et al. 2009). Sugamura et al. also showed that rimonabant reduced atherosclerotic lesions, and this was associated with increases in serum adiponectin, a protein involved in fatty acid degradation, and HDL cholesterol (Sugamura et al. 2010). Second, CB1 antagonism inhibits proliferation and migration of vascular smooth muscle cells. Reduced proliferation and migration of rimonabanttreated human coronary artery smooth muscle cells was observed in parallel to decreased ERK1/2 activation (Rajesh et al. 2008). Note, however, that clinical trials (STRADIVARIUS and AUDITOR) failed to demonstrate the ability of rimonabant to delay atherosclerotic progression (Nissen et al. 2008; O'Leary et al. 2011), but the STRADIVARIUS trial showed a favorable effect of rimonabant on HDL elevation and triglyceride decrease.

\subsubsection{Ischemia/reperfusion injury}

It is generally accepted that activation of cannabinoid receptors protects the heart against ischemia-reperfusion injury, primarily via $\mathrm{CB} 2$ receptor activation. Lagneux and Lamontagne first reported that the cardioprotective effects of lipopolysaccharide following 
ischemia/reperfusion, namely infarct size reduction and improved myocardial contractility, were blocked by a CB2 receptor antagonist (Lagneux and Lamontagne 2001). Similar effects were reported subsequently for various endocannabinoids (anandamide, 2-AG and palmitoylethanolamide) (Lepicier et al. 2003; Li et al. 2013) and synthetic agonists (JWH-015 and ACEA) (Lepicier et al. 2003). A CB2 receptor antagonist completely abolished the reduction of infarct size by all of these compounds, whereas a CB1 receptor antagonist only partially blocked 2-AG-elicited effects (Lepicier et al. 2003). Possible mechanisms include CB2dependent activation of P13K/Akt, p38/ERK1/2, and PKC, as well as inhibition of TNF- $\alpha$ and ROS (Lepicier et al. 2003; Li et al. 2013; Wang et al. 2012).

\subsubsection{Cardiac hypertrophy and heart failure}

As cardiac hypertrophy is a convergence point of risk factors for heart failure, there has been interest in the role of cannabinoid signaling. Anandamide and its metabolically-stable analog, R-methanandamide, suppressed hypertrophic indicators including cardiomyocyte enlargement and fetal gene activation (i.e. the brain natriuretic peptide gene) elicited by endothelin-1 in isolated neonatal rat ventricular myocytes (Lu et al. 2014). The ability of Rmethanandamide to suppress myocyte enlargement and fetal gene activation was mediated by CB2 and CB1 receptors, respectively. Accordingly, a CB2-selective agonist, JWH-133, prevented only myocyte enlargement but not BNP gene activation. A CB1/CB2 dual agonist with limited brain penetration, CB-13, inhibited both hypertrophic indicators. CB-13 activated AMPactivated protein kinase (AMPK) and, in an AMPK-dependent manner, endothelial nitric oxide synthase (eNOS). Disruption of AMPK signaling, using compound C or shRNA knockdown, and eNOS inhibition using L-NIO abolished the anti-hypertrophic actions of CB-13 (Lu et al. 2014). 
Liao et al. also queried a potential protective role of CB1 receptors by exposing CB1deficient mice to transverse aortic constriction (TAC). CB1-deficient TAC mice exhibited higher mortality, more severe lung edema, and greater epinephrine and norepinephrine levels compared to wild-type TAC mice and CB1-deficient sham groups. They further demonstrated more advanced LV hypertrophy and contractile impairment, and this was associated with augmented MAPK (p38 and ERK1/2) activation. In wild-type TAC mice, CB1 agonism ameliorated lung edema, reduced plasma epinephrine and norepinephrine levels, and activated AMP-activated protein (AMPK) (Liao et al. 2012). CB1 receptor activation also suppressed MAPKs in cultured neonatal rat cardiac myocytes treated by isoproterenol (Liao et al. 2013). Results generated by Wagner et al. agreed with the protective role of CB1 in a rat model of post-infarction cardiac remodeling (Wagner et al. 2003). However, contradictory results suggest that CB1 antagonism improves cardiac performance. Mukhopadhyay et al. generated heart failure in mice using doxorubicin, an anti-cancer drug with severe cardiotoxicity. Cardiac performance-related parameters, including ejection fraction, cardiac output, contractility and apoptosis, deteriorated in response to doxorubicin, whereas $\mathrm{CB} 1$ antagonists rimonabant and AM281 were protective (Mukhopadhyay et al. 2007). More recently, Lin et al. showed that the LVH and fibrosis found in mouse model of uremic cardiomyopathy were attenuated by a CB1 antagonist. Also, in an in vitro model (indoxyl sulfate treated H9c2 cells), expression of fibrotic markers (collagen I, TGF$\beta$ and $\alpha$-smooth muscle actin) was attenuated by a CB1 receptor antagonist or siRNA knockdown of CB1, vis-à-vis inhibition of Akt (Lin et al. 2015).

Regarding CB2 receptors, Weis et al. observed significant elevation of CB2 receptor expression in LV myocardium and endocannabinoids in blood circulation from patients with chronic heart failure, whereas CB1 receptor expression was down-regulated. These results 
suggest activation of the endocannabinoid system during chronic heart failure, and in particular, of CB2 receptors (Weis et al. 2010). Increased CB2 receptor expression also occurs in patients with aortic stenosis and severe hypertrophic markers (Duerr et al. 2013). However, it is not clear whether this is a compensatory defense mechanism or a detrimental factor.

Collectively, extant evidence reveals contradictory effects of CB1 activation, and the role of CB2 remains unclear. This suggests that manipulation of cannabinoid signaling as a novel therapeutic approach to cardioprotection requires further investigation.

\subsection{Endocannabinoid system and mitochondrial function}

The endocannabinoid system is involved in various energy regulation processes, and it has been implicated in the regulation of appetite, body weight and diabetes (Horvath et al. 2012; C. Li et al. 2011). For example, CB1 antagonism reduced hepatic triglycerides, increased expression of genes involved in fatty acid oxidation, and improved insulin sensitivity (Tam et al. 2010). Mitochondria are therefore proposed as reasonable targets of the endocannabinoid system. Recently, studies on the endocannabinoid system and mitochondrial function have emerged. For example, Zaccagnino et al. observed reduced ATP synthesis without mitochondrial $\Delta \psi_{\mathrm{m}} \operatorname{loss}$ in isolated liver mitochondria treated by anandamide (Zaccagnino et al. 2011). Athanasiou et al. reported decreased mitochondrial $\Delta \psi_{\mathrm{m}}$ and oxygen consumption in response to three cannabinoids: anandamide, THC, and the synthetic analog HU 210. Also, activities of ETC complexes I-III and cell viability were reduced, but only at concentrations higher than $10 \mu \mathrm{M}$, indicating concentration-dependent effects on mitochondrial function and integrity (Athanasiou et al. 2007). A few studies found cannabinoid receptor-independent effects of endocannabinoids on mitochondrial-dependent apoptosis by modulating the membrane fluidity, but again, at concentrations higher than $10 \mu \mathrm{M}$ (Catanzaro et al. 2009; Siegmund et al. 2007). Nevertheless, 
there is evidence to suggest that $\mathrm{CB}$ receptors regulate mitochondrial function, as discussed below.

\subsubsection{Mitochondrial effects of $\mathrm{CB} 1$ receptors}

CB1 receptors have been identified on mitochondrial membranes of mouse neuron cells, and account for approximately $15 \%$ of the total cellular amount (Benard et al. 2012). Fisar et al. reported that activation of CB1 receptors significantly reduced the activity of ETC complex I and II, but not complex IV in isolated mitochondria from pig brain (Fisar et al. 2014). CB1 receptor activation also reduced mitochondrial oxygen consumption and biogenesis parameters, such as mitochondrial mass and mitochondrial DNA amount, in mouse muscle and liver, as well as human white adipose tissue (Tedesco et al. 2010). In contrast, a CB1 antagonist increased fatty acid oxidation, reduced obesity in high-fat-diet mice (Jbilo et al. 2005), and prevented high-fatinduced cardiometabolic abnormalities in diabetic rats (Vijayakumar et al. 2012). This deregulation of mitochondrial function by CB1 receptors might be attributed to depressed pAMPK and eNOS (Tedesco et al. 2010). In summary, existing evidence suggests that CB1 receptors negatively mediate mitochondrial biogenesis and fatty acid oxidation.

\subsubsection{Mitochondrial effects of $\mathrm{CB} 2$ receptors}

In contrast, studies suggest protective effects of $\mathrm{CB} 2$ receptor activation on mitochondrial performance. $\mathrm{CB} 2$ receptor activation slowed down neuron degeneration by preventing mitochondrial apoptotic pathways (Latini et al. 2014). In a rat model of myocardial ischemia/reperfusion, CB2 receptor activation by JWH133 inhibited mPT, mitochondrial membrane depolarization, cytochrome c release, and apoptosis, which were abolished by ERK1/2 inhibitor. Such effects were used to explain the cardioprotective actions of CB2 receptors against ischemia/reperfusion injury (Li et al. 2014; Li et al. 2013). Cardiac myocytes 
exposed to the pro-hypertrophic agonist, endothelin-1, exhibited mitochondrial membrane depolarization in the presence of either palmitate or glucose as primary energy substrate, decreased mitochondrial bioenergetics and expression of genes related to fatty acid oxidation (i.e. PGC-1 $\alpha$, a driver of mitochondrial biogenesis, and CPT-1 $\beta$, facilitator of fatty acid uptake); CB-13, a dual agonist of CB1 and CB2 receptors corrected these parameters in an AMPKdependent manner, and it was speculated that this was due to actions mediated by CB2 rather than CB1 receptors (Lu et al. 2014). Contrary to CB1, CB2 receptor activation exhibits antiobesity effects (Agudo et al. 2010; Verty et al. 2015); a possible mechanism is the stimulation of palmitate oxidation and related proteins, which is mediated by cAMP/PKA/sirtuin 1 (SIRT1)/PGC-1 $\alpha$ signaling cascades (Zheng et al. 2013).

Taken in context with other studies on $\mathrm{CB}$ receptors, interventions that target $\mathrm{CB} / \mathrm{AMPK}$ signaling might represent a novel therapeutic approach to address the multi-factorial problem of cardiovascular disease.

4. Regulation of endocannabinoid system components

Endocannabinoid and cannabinoid receptor levels may be altered by various factors such as stress, inflammation, high-fat diet, obesity, diabetes, and dietary fatty acid consumption.

\subsection{Stress}

Stress, depression, and anxiety are known to alter endocannabinoid levels. Memory retrieval in rats that underwent stressful training elicited an increase in 2-AG and a corresponding decrease in the activity of the 2-AG-degrading enzyme MAGL (Morena et al. 2015). A rat model of early life stress created by maternal deprivation also increased levels of endocannabinoid system components (CB1, CB2, TRPV1, GPR55, as well as endocannabinoid synthase and hydrolase) in frontal cortex and hippocampus of adolescent male and female rats 
respectively (Marco et al. 2014). In addition, serum levels of endocannabinoids were evaluated in female patients with depression and anxiety. This study reported an increase in anandamide and 2-AG in patients with mild depression; however, 2-AG levels were markedly reduced in patients with advanced depression, and tended to decline with prolonged progression. Unlike the association of 2-AG levels with depression, anandamide was found to be negatively correlated with degree of anxiety (Hill et al. 2008).

\subsection{Inflammation}

Inflammatory conditions are often associated with elevated CB2 receptor expression. Multiple sclerosis patients exhibit higher CB2 expression in B cells, and higher anandamide levels in B cells, natural killer cells, and T cells (Sanchez Lopez et al. 2015). CB2 expression was also up-regulated in mouse models of, and humans, with colitis (Storr et al. 2009; Wright et al. 2005). Finally, anandamide, 2-AG, $\mathrm{CB} 1$ and $\mathrm{CB} 2$ receptors were detected in synovial membranes from patients with rheumatoid arthritis, but not healthy volunteers (Gui et al. 2015).

\subsection{High-fat diet, obesity, and diabetes}

High-fat diet, obesity, and diabetes are well-known conditions that involve altered levels of endocannabinoid system components. A marked increase in hepatic anandamide levels was detected in mice fed high-fat diets $(60 \mathrm{en} \%)$ for three weeks, although the extent of increase declined after 14 weeks. This elevation of anandamide was associated with a reduction in FAAH activity (Osei-Hyiaman et al. 2005). In contrast, no changes in anandamide and 2-AG were observed in rats fed high-saturated fat diets (palm oil-rich diets, 38 en\%) for one week (Artmann et al. 2008). Nevertheless, obese patients exhibit higher endocannabinoid levels in visceral fat and serum (Matias et al. 2006). Engeli et al. reported that compared to lean female subjects, obese females exhibited $35 \%$ and $52 \%$ increases in circulating anandamide and $2-\mathrm{AG}$ 
respectively, and a reduction of FAAH expression in adipose tissue (Engeli et al. 2005). Cote et al. observed a positive correlation between plasma 2-AG level and body mass index, intraabdominal adiposity and fasting insulin level in males. However, a negative correlation was found between anandamide and intra-abdominal adiposity (Cote et al. 2007). Annuzzi et al. assessed the levels of endocannabinoids in subcutaneous adipose tissue, and found increased anandamide and decreased 2-AG in patients with both obesity and type 2 diabetes, but not in non-diabetic obese patients (Annuzzi et al. 2010). Increased FAAH and MAGL were detected in various adipose tissues (subcutaneous abdominal, visceral, and epididymal) in obese rats with or without diabetes. However, no changes in FAAH and MAGL were found in obese humans (Cable et al. 2014). The interaction between obesity and endocannabinoid levels remains unclear, and existing evidence appear to be controversial. However, endocannabinoid levels are seemingly not influenced solely by high-saturated fat diets; perhaps other mediators implicated in diabetes, such as leptin and insulin, may be key players (Matias et al. 2006). Indeed, intravenous injection of leptin significantly reduced anandamide and 2-AG levels in hypothalamus of normal rats and obese mice (Di Marzo et al. 2001). Insulin treatment decreased anandamide and 2-AG levels in healthy adipocytes, but not in insulin-resistant adipocytes (D'Eon et al. 2008).

\subsection{Dietary consumption of polyunsaturated fatty acids (PUFA)}

Anandamide and 2-AG are derived from arachidonic acid, an omega-6 PUFA. Thus, endocannabinoid levels may be modified by diets that affect the arachidonic acid content in tissue phospholipids. Indeed, increasing dietary linoleic acid (omega-6) (from 1 en\% to 8 en\%) elevated anandamide and 2-AG levels in mouse liver and resulted in weight gain, although total dietary fat remained unchanged (Alvheim et al. 2012). Also, the effects of omega-3 PUFA on 
endocannabinoid levels were evaluated in mice brain. Watanabe et al. found that an omega-3 PUFA-deficient diet significantly increased 2-AG content in brain, whereas short-term consumption of a docosahexaenoic acid (DHA)-rich diet reduced the arachidonic acid content in phospholipids and brain 2-AG levels (Watanabe et al. 2003). These results were consistent with the findings of Wood et al., which showed that fish oil supplementation for 2 weeks is sufficient to affect fatty acid composition by enhancing DHA and eicosapentaenoic acid (EPA; omega-3 PUFA) levels, and down-regulated arachidonic acid and anandamide content in mouse brain and plasma (Wood et al. 2010). In addition, a human study investigated the effects of an omega-3rich diet on endocannabinoid levels in obese men. In this study, krill powder, which contains $61.8 \%$ krill oil (omega-3-rich oil), was provided to mildly obese men for 24 weeks. After 24 weeks, plasma levels of anandamide and its analogues plmitoylethanolamide and oleoylethanolamide were significantly reduced, as were triglycerides, but no weight loss was observed (Berge et al. 2013). Although more studies are needed, the existing evidence implies that dietary fatty acid composition influences endocannabinoid levels by manipulating omega3/omega-6 balance, which in turn regulates the level of arachidonic acid.

\section{Conclusions}

There is significant interest in manipulation of the endocannabinoid system as a therapeutic approach to treat disorders such as metabolic syndrome, inflammatory and neuropathic pain, and multiple sclerosis (Hosking and Zajicek 2008; Palazuelos et al. 2006). Unfortunately, therapeutic use of cannabinoids is impeded by psychotropic side effects including dysphoria, memory impairment, reduced concentration, disorientation, motor incoordination, and possibly addiction. This undesirable psychoactivity is mediated by central CB1 receptors (Hosking and Zajicek 2008; Howlett et al. 2002; Kunos et al. 2009; Piomelli 2003), so alternate strategies like using 
CB2-selective agonists and/or peripherally-restricted CB1/CB2 dual agonists have been proposed (Gertsch et al. 2008; Hosking and Zajicek 2008; Kunos et al. 2009; Palazuelos et al. 2006). Collectively, the numerous studies on cannabinoid and CB receptor-mediated effects suggest that interventions that target cannabinoid signaling might represent a novel therapeutic approach to address multiple disease states and conditions.

6. Acknowledgements

This work was supported by the Canadian Institutes of Health Research (MOP 130297) and a studentship from the Manitoba Health Research Council/St. Boniface Hospital Foundation (Y.L.). 


\section{References}

Abadji, V., Lin, S., Taha, G., Griffin, G., Stevenson, L.A., Pertwee, R.G., et al. 1994. (R)methanandamide: a chiral novel anandamide possessing higher potency and metabolic stability. J. Med. Chem. 37(12): 1889-1893.

Agudo, J., Martin, M., Roca, C., Molas, M., Bura, A.S., Zimmer, A., et al. 2010. Deficiency of CB2 cannabinoid receptor in mice improves insulin sensitivity but increases food intake and obesity with age. Diabetologia, 53(12): 2629-2640.

Ahmed, A., van der Marck, M.A., van den Elsen, G., and Olde Rikkert, M. 2015. Cannabinoids in late-onset Alzheimer's disease. Clin. Pharmacol. Ther. 97(6), 597-606.

Alvheim, A.R., Malde, M.K., Osei-Hyiaman, D., Lin, Y.H., Pawlosky, R.J., Madsen, L., et al. 2012. Dietary linoleic acid elevates endogenous 2-AG and anandamide and induces obesity. Obesity (Silver Spring), 20(10): 1984-1994.

Annuzzi, G., Piscitelli, F., Di Marino, L., Patti, L., Giacco, R., Costabile, G., et al. 2010. Differential alterations of the concentrations of endocannabinoids and related lipids in the subcutaneous adipose tissue of obese diabetic patients. Lipids Health Dis. 9: 43.

Arrabal, S., Lucena, M.A., Canduela, M.J., Ramos-Uriarte, A., Rivera, P., Serrano, A., et al. 2015. Pharmacological Blockade of Cannabinoid CB1 Receptors in Diet-Induced Obesity Regulates Mitochondrial Dihydrolipoamide Dehydrogenase in Muscle. PLoS One, 10(12): e0145244.

Artmann, A., Petersen, G., Hellgren, L.I., Boberg, J., Skonberg, C., Nellemann, C., et al. 2008. Influence of dietary fatty acids on endocannabinoid and $\mathrm{N}$-acylethanolamine levels in rat brain, liver and small intestine. Biochim. Biophys. Acta., 1781(4), 200-212. 
Aso, E., Palomer, E., Juves, S., Maldonado, R., Munoz, F.J., and Ferrer, I. 2012. CB1 agonist ACEA protects neurons and reduces the cognitive impairment of AbetaPP/PS1 mice. J. Alzheimers Dis. 30(2): 439-459.

Athanasiou, A., Clarke, A.B., Turner, A.E., Kumaran, N.M., Vakilpour, S., Smith, P.A., et al. 2007. Cannabinoid receptor agonists are mitochondrial inhibitors: a unified hypothesis of how cannabinoids modulate mitochondrial function and induce cell death. Biochem. Biophys. Res. Commun. 364(1): 131-137.

Bambico, F.R., Katz, N., Debonnel, G., and Gobbi, G. 2007. Cannabinoids elicit antidepressantlike behavior and activate serotonergic neurons through the medial prefrontal cortex. J. Neurosci. 27(43): 11700-11711.

Basavarajappa, B.S. 2007. Critical enzymes involved in endocannabinoid metabolism. Protein Pept. Lett. 14(3): 237-246.

Battista, N., Di Tommaso, M., Bari, M., and Maccarrone, M. 2012. The endocannabinoid system: an overview. Front Behav. Neurosci. 6: 9.

Battista, N., Fezza, F., Finazzi-Agro, A., and Maccarrone, M. 2006. The endocannabinoid system in neurodegeneration. Ital. J. Biochem. 55(3-4): 283-289.

Beal, J.E., Olson, R., Laubenstein, L., Morales, J.O., Bellman, P., Yangco, B., et al. 1995. Dronabinol as a treatment for anorexia associated with weight loss in patients with AIDS. J. Pain Symptom Manage. 10(2): 89-97.

Becker, D.E. 2010. Nausea, vomiting, and hiccups: a review of mechanisms and treatment. Anesth. Prog. 57(4): 150-156; quiz 157. 
Beltramo, M., Bernardini, N., Bertorelli, R., Campanella, M., Nicolussi, E., Fredduzzi, S., et al. 2006. CB2 receptor-mediated antihyperalgesia: possible direct involvement of neural mechanisms. Eur. J. Neurosci. 23(6): 1530-1538.

Beltramo, M., Stella, N., Calignano, A., Lin, S.Y., Makriyannis, A., and Piomelli, D. 1997. Functional role of high-affinity anandamide transport, as revealed by selective inhibition. Science, 277(5329): 1094-1097.

Ben-Shabat, S., Fride, E., Sheskin, T., Tamiri, T., Rhee, M.H., Vogel, Z., et al. 1998. An entourage effect: inactive endogenous fatty acid glycerol esters enhance 2-arachidonoyl-glycerol cannabinoid activity. Eur. J. Pharmacol. 353(1): 23-31.

Benard, G., Massa, F., Puente, N., Lourenco, J., Bellocchio, L., Soria-Gomez, E., et al. 2012. Mitochondrial CB(1) receptors regulate neuronal energy metabolism. Nat. Neurosci. 15(4): 558564.

Berge, K., Piscitelli, F., Hoem, N., Silvestri, C., Meyer, I., Banni, S., et al. 2013. Chronic treatment with krill powder reduces plasma triglyceride and anandamide levels in mildly obese men. Lipids Health Dis. 12: 78.

Bhattacharyya, S., Morrison, P.D., Fusar-Poli, P., Martin-Santos, R., Borgwardt, S., WintonBrown, T., et al. 2010. Opposite effects of delta-9-tetrahydrocannabinol and cannabidiol on human brain function and psychopathology. Neuropsychopharmacology, 35(3): 764-774. Bilfinger, T.V., Salzet, M., Fimiani, C., Deutsch, D.G., Tramu, G., and Stefano, G.B. 1998. Pharmacological evidence for anandamide amidase in human cardiac and vascular tissues. Int. J. Cardiol. 64 Suppl 1: S15-22. 
Bisogno, T., Berrendero, F., Ambrosino, G., Cebeira, M., Ramos, J.A., Fernandez-Ruiz, J.J., et al. 1999. Brain regional distribution of endocannabinoids: implications for their biosynthesis and biological function. Biochem. Biophys. Res. Commun. 256(2): 377-380.

Blankman, J.L., Simon, G.M., and Cravatt, B.F. 2007. A comprehensive profile of brain enzymes that hydrolyze the endocannabinoid 2-arachidonoylglycerol. Chem. Biol. 14(12): 13471356.

Bonhaus, D.W., Chang, L.K., Kwan, J., and Martin, G.R. 1998. Dual activation and inhibition of adenylyl cyclase by cannabinoid receptor agonists: evidence for agonist-specific trafficking of intracellular responses. J. Pharmacol. Exp. Ther. 287(3): 884-888.

Bonz, A., Laser, M., Kullmer, S., Kniesch, S., Babin-Ebell, J., Popp, V., et al. 2003.

Cannabinoids acting on CB1 receptors decrease contractile performance in human atrial muscle.

J. Cardiovasc. Pharmacol. 41(4): 657-664.

Bouchard, J.F., Lepicier, P., and Lamontagne, D. 2003. Contribution of endocannabinoids in the endothelial protection afforded by ischemic preconditioning in the isolated rat heart. Life Sci. 72(16), 1859-1870.

Brown, A.J., and Robin Hiley, C. 2009. Is GPR55 an anandamide receptor? Vitam. Horm. 81: $111-137$.

Brusco, A., Tagliaferro, P., Saez, T., and Onaivi, E.S. 2008. Postsynaptic localization of CB2 cannabinoid receptors in the rat hippocampus. Synapse, 62(12): 944-949.

Cable, J.C., Tan, G.D., Alexander, S.P., and O'Sullivan, S.E. 2014. The effects of obesity, diabetes and metabolic syndrome on the hydrolytic enzymes of the endocannabinoid system in animal and human adipocytes. Lipids Health Dis. 13: 43. 
Cadas, H., di Tomaso, E., and Piomelli, D. 1997. Occurrence and biosynthesis of endogenous cannabinoid precursor, N-arachidonoyl phosphatidylethanolamine, in rat brain. J. Neurosci. 17(4): 1226-1242.

Cadas, H., Gaillet, S., Beltramo, M., Venance, L., and Piomelli, D. 1996. Biosynthesis of an endogenous cannabinoid precursor in neurons and its control by calcium and cAMP. J. Neurosci. 16(12): 3934-3942.

Caffarel, M.M., Andradas, C., Mira, E., Perez-Gomez, E., Cerutti, C., Moreno-Bueno, G., et al. 2010. Cannabinoids reduce ErbB2-driven breast cancer progression through Akt inhibition. Mol. Cancer, 9: 196.

Callen, L., Moreno, E., Barroso-Chinea, P., Moreno-Delgado, D., Cortes, A., Mallol, J., et al. 2012. Cannabinoid receptors CB1 and CB2 form functional heteromers in brain. J. Biol. Chem. 287(25): 20851-20865.

Carnevali, L., Vacondio, F., Rossi, S., Callegari, S., Macchi, E., Spadoni, G., et al. 2015. Antidepressant-like activity and cardioprotective effects of fatty acid amide hydrolase inhibitor URB694 in socially stressed Wistar Kyoto rats. Eur. Neuropsychopharmacol. 25(11): 2157-2169. Carruba, M.O., Bondiolotti, G., Picotti, G.B., Catteruccia, N., and Da Prada, M. 1987. Effects of diethyl ether, halothane, ketamine and urethane on sympathetic activity in the rat. Eur. J. Pharmacol. 134(1): 15-24.

Catanzaro, G., Rapino, C., Oddi, S., and Maccarrone, M. 2009. Anandamide increases swelling and reduces calcium sensitivity of mitochondria. Biochem. Biophys. Res. Commun. 388(2): 439442. 
Christensen, R., Kristensen, P.K., Bartels, E.M., Bliddal, H., and Astrup, A. 2007. Efficacy and safety of the weight-loss drug rimonabant: a meta-analysis of randomised trials. Lancet, 370(9600): 1706-1713.

Chung, S.C., Hammarsten, P., Josefsson, A., Stattin, P., Granfors, T., Egevad, L., et al. 2009. A high cannabinoid $\mathrm{CB}(1)$ receptor immunoreactivity is associated with disease severity and outcome in prostate cancer. Eur. J. Cancer, 45(1): 174-182.

Cianchi, F., Papucci, L., Schiavone, N., Lulli, M., Magnelli, L., Vinci, M.C., et al. 2008.

Cannabinoid receptor activation induces apoptosis through tumor necrosis factor alpha-mediated ceramide de novo synthesis in colon cancer cells. Clin. Cancer. Res. 14(23): 7691-7700.

Clapper, J.R., Moreno-Sanz, G., Russo, R., Guijarro, A., Vacondio, F., Duranti, A., et al. 2010. Anandamide suppresses pain initiation through a peripheral endocannabinoid mechanism. Nat. Neurosci. 13(10): 1265-1270.

Cluny, N.L., Vemuri, V.K., Chambers, A.P., Limebeer, C.L., Bedard, H., Wood, J.T., et al. 2010. A novel peripherally restricted cannabinoid receptor antagonist, AM6545, reduces food intake and body weight, but does not cause malaise, in rodents. Br. J. Pharmacol. 161(3): 629-642. Correa, F., Docagne, F., Mestre, L., Clemente, D., Hernangomez, M., Loria, F., et al. 2009. A role for CB2 receptors in anandamide signalling pathways involved in the regulation of IL-12 and IL-23 in microglial cells. Biochem. Pharmacol. 77(1): 86-100.

Cota, D., Marsicano, G., Tschop, M., Grubler, Y., Flachskamm, C., Schubert, M., et al. 2003. The endogenous cannabinoid system affects energy balance via central orexigenic drive and peripheral lipogenesis. J. Clin. Invest. 112(3): 423-431. 
Cote, M., Matias, I., Lemieux, I., Petrosino, S., Almeras, N., Despres, J.P., et al. 2007.

Circulating endocannabinoid levels, abdominal adiposity and related cardiometabolic risk factors in obese men. Int. J. Obes. (Lond.), 31(4): 692-699.

Cravatt, B.F., Demarest, K., Patricelli, M.P., Bracey, M.H., Giang, D.K., Martin, B.R., et al. 2001. Supersensitivity to anandamide and enhanced endogenous cannabinoid signaling in mice lacking fatty acid amide hydrolase. Proc. Natl. Acad. Sci. U.S.A. 98(16): 9371-9376.

Cravatt, B.F., and Lichtman, A.H. 2002. The enzymatic inactivation of the fatty acid amide class of signaling lipids. Chem. Phys. Lipids, 121(1-2): 135-148.

Curtis, A., Mitchell, I., Patel, S., Ives, N., and Rickards, H. 2009. A pilot study using nabilone for symptomatic treatment in Huntington's disease. Mov. Disord. 24(15): 2254-2259.

D'Eon, T.M., Pierce, K.A., Roix, J.J., Tyler, A., Chen, H., and Teixeira, S.R. 2008. The role of adipocyte insulin resistance in the pathogenesis of obesity-related elevations in endocannabinoids. Diabetes, 57(5): 1262-1268.

Darmani, N.A. 2001. Delta-9-tetrahydrocannabinol differentially suppresses cisplatin-induced emesis and indices of motor function via cannabinoid $\mathrm{CB}(1)$ receptors in the least shrew.

Pharmacol. Biochem. Behav.,69(1-2): 239-249.

de Lago, E., Moreno-Martet, M., Cabranes, A., Ramos, J.A., and Fernandez-Ruiz, J. 2012. Cannabinoids ameliorate disease progression in a model of multiple sclerosis in mice, acting preferentially through CB1 receptor-mediated anti-inflammatory effects. Neuropharmacology, 62(7): 2299-2308.

De Petrocellis, L, Melck, D, Palmisano, A,, Bisogno, T,, Laezza, C., Bifulco, M., et al. 1998. The endogenous cannabinoid anandamide inhibits human breast cancer cell proliferation. Proc.

Natl. Acad. Sci. U.S.A. 95(14): 8375-8380. 
Demuth, D.G., and Molleman, A. 2006. Cannabinoid signalling. Life Sci. 78(6): 549-563.

Deutsch, D.G., and Chin, S.A. 1993. Enzymatic synthesis and degradation of anandamide, a cannabinoid receptor agonist. Biochem. Pharmacol. 46(5): 791-796.

Devane, W.A., Hanus, L., Breuer, A., Pertwee, R.G., Stevenson, L.A., Griffin, G., et al. 1992. Isolation and structure of a brain constituent that binds to the cannabinoid receptor. Science, 258(5090): 1946-1949.

Di Marzo, V., and Despres, J.P. 2009. CB1 antagonists for obesity--what lessons have we learned from rimonabant? Nat. Rev. Endocrinol. 5(11): 633-638.

Di Marzo, V., Goparaju, S.K., Wang, L., Liu, J., Batkai, S., Jarai, Z., et al. 2001. Leptinregulated endocannabinoids are involved in maintaining food intake. Nature, 410(6830): 822825.

Dinh, T.P., Carpenter, D., Leslie, F.M., Freund, T.F., Katona, I., Sensi, S.L., et al. 2002. Brain monoglyceride lipase participating in endocannabinoid inactivation. Proc. Natl. Acad. Sci. U.S.A. 99(16): 10819-10824.

Dinh, T.P., Freund, T.F., and Piomelli, D. 2002. A role for monoglyceride lipase in 2arachidonoylglycerol inactivation. Chem. Phys. Lipids, 121(1-2): 149-158.

Duerr, G.D., Heinemann, J.C., Dunkel, S., Zimmer, A., Lutz, B., Lerner, R., et al. 2013. Myocardial hypertrophy is associated with inflammation and activation of endocannabinoid system in patients with aortic valve stenosis. Life Sci. 92(20-21): 976-983.

Duran, M., Perez, E., Abanades, S., Vidal, X., Saura, C., Majem, M., et al. 2010. Preliminary efficacy and safety of an oromucosal standardized cannabis extract in chemotherapy-induced nausea and vomiting. Br. J. Clin. Pharmacol. 70(5): 656-663. 
Dziadulewicz, E.K., Bevan, S.J., Brain, C.T., Coote, P.R., Culshaw, A.J., Davis, A.J., et al. 2007. Naphthalen-1-yl-(4-pentyloxynaphthalen-1-yl)methanone: a potent, orally bioavailable human CB1/CB2 dual agonist with antihyperalgesic properties and restricted central nervous system penetration. J. Med. Chem. 50(16): 3851-3856.

El Manira, A., and Kyriakatos, A. 2010. The role of endocannabinoid signaling in motor control. Physiology (Bethesda), 25(4): 230-238.

Eljaschewitsch, E., Witting, A., Mawrin, C., Lee, T., Schmidt, P.M., Wolf, S., et al. 2006. The endocannabinoid anandamide protects neurons during CNS inflammation by induction of MKP1 in microglial cells. Neuron, 49(1): 67-79.

Engeli, S., Bohnke, J., Feldpausch, M., Gorzelniak, K., Janke, J., Batkai, S., et al. 2005. Activation of the peripheral endocannabinoid system in human obesity. Diabetes, 54(10): 28382843.

Faure, L., Nagarajan, S., Hwang, H., Montgomery, C.L., Khan, B.R., John, G., et al. 2014. Synthesis of phenoxyacyl-ethanolamides and their effects on fatty acid amide hydrolase activity. J. Biol. Chem. 289(13): 9340-9351.

Felder, C.C., Joyce, K.E., Briley, E.M., Mansouri, J., Mackie, K., Blond, O., et al. 1995. Comparison of the pharmacology and signal transduction of the human cannabinoid CB1 and CB2 receptors. Mol. Pharmacol. 48(3): 443-450.

Felder, C.C., Nielsen, A., Briley, E.M., Palkovits, M., Priller, J., Axelrod, J., et al. 1996. Isolation and measurement of the endogenous cannabinoid receptor agonist, anandamide, in brain and peripheral tissues of human and rat. FEBS Lett. 393(2-3): 231-235.

Fernandes, E.S., Fernandes, M.A., and Keeble, J.E. 2012. The functions of TRPA1 and TRPV1: moving away from sensory nerves. Br. J. Pharmacol. 166(2): 510-521. 
Fimiani, C., Mattocks, D., Cavani, F., Salzet, M., Deutsch, D.G., Pryor, S., et al. 1999. Morphine and anandamide stimulate intracellular calcium transients in human arterial endothelial cells: coupling to nitric oxide release. Cell. Signal. 11(3): 189-193.

Fisar, Z., Singh, N., and Hroudova, J. 2014. Cannabinoid-induced changes in respiration of brain mitochondria. Toxicol. Lett. 231(1): 62-71.

Fitzgerald, K.T., Bronstein, A.C., and Newquist, K.L. 2013. Marijuana poisoning. Top. Companion Anim. Med. 28(1): 8-12.

Fu, J., Bottegoni, G., Sasso, O., Bertorelli, R., Rocchia, W., Masetti, M., et al. 2012. A catalytically silent FAAH-1 variant drives anandamide transport in neurons. Nat. Neurosci. 15(1): 64-69.

Galve-Roperh, I., Sanchez, C., Cortes, M.L., Gomez del Pulgar, T., Izquierdo, M., and Guzman, M. 2000. Anti-tumoral action of cannabinoids: involvement of sustained ceramide accumulation and extracellular signal-regulated kinase activation. Nat. Med. 6(3): 313-319.

Garcia, C., Palomo-Garo, C., Garcia-Arencibia, M., Ramos, J., Pertwee, R., and Fernandez-Ruiz, J. 2011. Symptom-relieving and neuroprotective effects of the phytocannabinoid Delta(9)-THCV in animal models of Parkinson's disease. Br. J. Pharmacol. 163(7): 1495-1506.

Garcia-Arencibia, M., Gonzalez, S., de Lago, E., Ramos, J.A., Mechoulam, R., and FernandezRuiz, J. 2007. Evaluation of the neuroprotective effect of cannabinoids in a rat model of Parkinson's disease: importance of antioxidant and cannabinoid receptor-independent properties. Brain Res. 1134(1): 162-170.

Gates, P.J., Albertella, L., and Copeland, J. 2014. The effects of cannabinoid administration on sleep: a systematic review of human studies. Sleep Med. Rev. 18(6): 477-487. 
Gebremedhin, D., Lange, A.R., Campbell, W.B., Hillard, C.J., and Harder, D.R. 1999. Cannabinoid CB1 receptor of cat cerebral arterial muscle functions to inhibit L-type Ca2+ channel current. Am. J. Physiol. 276(6 Pt 2): H2085-2093.

Gertsch, J., Leonti, M., Raduner, S., Racz, I., Chen, J.Z., Xie, X.Q., et al. 2008. Betacaryophyllene is a dietary cannabinoid. Proc. Natl. Acad. Sci. U. S. A. 105(26): 9099-9104. Golech, S.A., McCarron, R.M., Chen, Y., Bembry, J., Lenz, F., Mechoulam, R., et al. 2004. Human brain endothelium: coexpression and function of vanilloid and endocannabinoid receptors. Brain Res. Mol. Brain Res. 132(1): 87-92.

Gong, J.P., Onaivi, E.S., Ishiguro, H., Liu, Q.R., Tagliaferro, P.A., Brusco, A., et al. 2006. Cannabinoid CB2 receptors: immunohistochemical localization in rat brain. Brain Res. 1071(1): $10-23$.

Gonzalez, S., Scorticati, C., Garcia-Arencibia, M., de Miguel, R., Ramos, J.A., and FernandezRuiz, J. 2006. Effects of rimonabant, a selective cannabinoid CB1 receptor antagonist, in a rat model of Parkinson's disease. Brain Res. 1073-1074: 209-219.

Gorelick, D.A., Heishman, S.J., Preston, K.L., Nelson, R.A., Moolchan, E.T., and Huestis, M.A. 2006. The cannabinoid CB1 receptor antagonist rimonabant attenuates the hypotensive effect of smoked marijuana in male smokers. Am. Heart J. 151(3): 754. e1-754. e5.

Grant, I., Atkinson, J.H., Gouaux, B., and Wilsey, B. 2012. Medical marijuana: clearing away the smoke. Open Neurol. J. 6: 18-25.

Grimaldi, C., Pisanti, S., Laezza, C., Malfitano, A.M., Santoro, A., Vitale, M., et al. 2006. Anandamide inhibits adhesion and migration of breast cancer cells. Exp. Cell Res. 312(4): 363373. 
Gui, H., Tong, Q., Qu, W., Mao, C.M., and Dai, S.M. 2015. The endocannabinoid system and its therapeutic implications in rheumatoid arthritis. Int. Immunopharmacol. 26(1): 86-91.

Gustafsson, S.B., Palmqvist, R., Henriksson, M.L., Dahlin, A.M., Edin, S., Jacobsson, S.O., et al. 2011. High tumour cannabinoid CB1 receptor immunoreactivity negatively impacts diseasespecific survival in stage II microsatellite stable colorectal cancer. PLoS One, 6(8): e23003. Harvey, B.S., Nicotra, L.L., Vu, M., and Smid, S.D. 2013. Cannabinoid CB2 receptor activation attenuates cytokine-evoked mucosal damage in a human colonic explant model without changing epithelial permeability. Cytokine, 63(2): 209-217.

Hashimotodani, Y., Ohno-Shosaku, T., Tanimura, A., Kita, Y., Sano, Y., Shimizu, T., et al. 2013. Acute inhibition of diacylglycerol lipase blocks endocannabinoid-mediated retrograde signalling: evidence for on-demand biosynthesis of 2-arachidonoylglycerol. J. Physiol. 591(19): $4765-4776$.

Heinbockel, T., Brager, D.H., Reich, C.G., Zhao, J., Muralidharan, S., Alger, B.E., et al. 2005. Endocannabinoid signaling dynamics probed with optical tools. J. Neurosci. 25(41): 9449-9459. Henstridge, C.M., Balenga, N.A., Ford, L.A., Ross, R.A., Waldhoer, M., and Irving, A.J. 2009. The GPR55 ligand L-alpha-lysophosphatidylinositol promotes RhoA-dependent Ca2+ signaling and NFAT activation. FASEB J. 23(1): 183-193.

Hernandez-Torres, G., Cipriano, M., Heden, E., Bjorklund, E., Canales, A., Zian, D., et al. 2014. A reversible and selective inhibitor of monoacylglycerol lipase ameliorates multiple sclerosis. Angew. Chem. Int. Ed. Engl. 53(50): 13765-13770.

Hill, M.N., Miller, G.E., Ho, W.S., Gorzalka, B.B., and Hillard, C.J. 2008. Serum endocannabinoid content is altered in females with depressive disorders: a preliminary report. Pharmacopsychiatry, 41(2): 48-53. 
Hillard, C.J., Manna, S., Greenberg, M.J., DiCamelli, R., Ross, R.A., Stevenson, L.A., et al. 1999. Synthesis and characterization of potent and selective agonists of the neuronal cannabinoid receptor (CB1). J. Pharmacol. Exp. Ther. 289(3): 1427-1433.

Ho, W.S., and Randall, M.D. 2007. Endothelium-dependent metabolism by endocannabinoid hydrolases and cyclooxygenases limits vasorelaxation to anandamide and 2arachidonoylglycerol. Br. J. Pharmacol. 150(5): 641-651.

Hohmann, A.G., Suplita, R.L., Bolton, N.M., Neely, M.H., Fegley, D., Mangieri, R., et al. 2005. An endocannabinoid mechanism for stress-induced analgesia. Nature, 435(7045): 1108-1112. Horvath, B., Mukhopadhyay, P., Hasko, G., and Pacher, P. 2012. The endocannabinoid system and plant-derived cannabinoids in diabetes and diabetic complications. Am. J. Pathol. 180(2): $432-442$.

Hosking, R.D., and Zajicek, J.P. 2008. Therapeutic potential of cannabis in pain medicine. Br. J. Anaesth. 101(1): 59-68.

Howlett, A.C., Barth, F., Bonner, T.I., Cabral, G., Casellas, P., Devane, W.A, et al. 2002. International Union of Pharmacology. XXVII. Classification of cannabinoid receptors. Pharmacol. Rev. 54(2): 161-202.

Hsiao, W.C., Shia, K.S., Wang, Y.T., Yeh, Y.N., Chang, C.P., Lin, Y., et al. 2015. A novel peripheral cannabinoid receptor 1 antagonist, BPR0912, reduces weight independently of food intake and modulates thermogenesis. Diabetes Obes. Metab. 17(5): 495-504.

Hu, D.L., Zhu, G., Mori, F., Omoe, K., Okada, M., Wakabayashi, K., et al. 2007. Staphylococcal enterotoxin induces emesis through increasing serotonin release in intestine and it is downregulated by cannabinoid receptor 1. Cell. Microbiol. 9(9): 2267-2277. 
Huang, W., Rubinstein, J., Prieto, A.R., Thang, L.V., and Wang, D.H. 2009. Transient receptor potential vanilloid gene deletion exacerbates inflammation and atypical cardiac remodeling after myocardial infarction. Hypertension, 53(2): 243-250.

Huestis, M.A., Boyd, S.J., Heishman, S.J., Preston, K.L., Bonnet, D., Le Fur, G., et al. 2007. Single and multiple doses of rimonabant antagonize acute effects of smoked cannabis in male cannabis users. Psychopharmacology (Berl.), 194(4): 505-515.

Huffman, J.W., Liddle, J., Yu, S., Aung, M.M., Abood, M.E., Wiley, J.L., et al. 1999. 3-(1',1'Dimethylbutyl)-1-deoxy-delta8-THC and related compounds: synthesis of selective ligands for the CB2 receptor. Bioorg. Med. Chem. 7(12): 2905-2914.

Ibrahim, M.M., Deng, H., Zvonok, A., Cockayne, D.A., Kwan, J., Mata, H.P., et al. 2003. Activation of CB2 cannabinoid receptors by AM1241 inhibits experimental neuropathic pain: pain inhibition by receptors not present in the CNS. Proc. Natl. Acad. Sci. U. S. A. 100(18): 10529-10533.

Jbilo, O., Ravinet-Trillou, C., Arnone, M., Buisson, I., Bribes, E., Peleraux, A., et al. 2005. The CB1 receptor antagonist rimonabant reverses the diet-induced obesity phenotype through the regulation of lipolysis and energy balance. FASEB J. 19(11): 1567-1569.

Jiang, L.S., Pu, J., Han, Z.H., Hu, L.H. and He, B.. 2009. Role of activated endocannabinoid system in regulation of cellular cholesterol metabolism in macrophages. Cardiovasc. Res. 81(4): $805-813$.

Jung, M., Calassi, R., Rinaldi-Carmona, M., Chardenot, P., Le Fur, G., Soubrie, P., et al. 1997. Characterization of $\mathrm{CB} 1$ receptors on rat neuronal cell cultures: binding and functional studies using the selective receptor antagonist SR 141716A. J. Neurochem. 68(1): 402-409. 
Karlsson, M., Contreras, J.A., Hellman, U., Tornqvist, H., and Holm, C. 1997. cDNA cloning, tissue distribution, and identification of the catalytic triad of monoglyceride lipase. Evolutionary relationship to esterases, lysophospholipases, and haloperoxidases. J. Biol. Chem. 272(43):, 27218-27223.

Karschner, E.L., Darwin, W.D., McMahon, R.P., Liu, F., Wright, S., Goodwin, R.S., et al. 2011. Subjective and physiological effects after controlled Sativex and oral THC administration. Clin. Pharmacol. Ther. 89(3): 400-407.

Katayama, K., Ueda, N., Katoh, I., and Yamamoto, S. 1999. Equilibrium in the hydrolysis and synthesis of cannabimimetic anandamide demonstrated by a purified enzyme. Biochim. Biophys. Acta, 1440(2-3): 205-214.

Kelsey, J.E., Harris, O., and Cassin J. 2009. The CB(1) antagonist rimonabant is adjunctively therapeutic as well as monotherapeutic in an animal model of Parkinson's disease. Behav. Brain Res. 203(2): 304-307.

Khanolkar, A.D., Abadji, V., Lin, S., Hill, W.A., Taha, G., Abouzid, K., et al. 1996. Head group analogs of arachidonylethanolamide, the endogenous cannabinoid ligand. J. Med. Chem. 39(22): 4515-4519.

Kim, J., and Li, Y. 2015. Chronic activation of CB2 cannabinoid receptors in the hippocampus increases excitatory synaptic transmission. J. Physiol. 593(4): 871-886.

Kirkham, T.C., Williams, C.M., Fezza, F., and Di Marzo, V. 2002. Endocannabinoid levels in rat limbic forebrain and hypothalamus in relation to fasting, feeding and satiation: stimulation of eating by 2-arachidonoyl glycerol. Br. J. Pharmacol. 136(4), 550-557.

Kondo, S., Kondo, H., Nakane, S., Kodaka, T., Tokumura, A., Waku, K., et al. 1998. 2-

Arachidonoylglycerol, an endogenous cannabinoid receptor agonist: identification as one of the 
major species of monoacylglycerols in various rat tissues, and evidence for its generation through CA2+-dependent and -independent mechanisms. FEBS Lett. 429(2): 152-156.

Krishnan, G., and Chatterjee, N. 2012. Endocannabinoids alleviate proinflammatory conditions by modulating innate immune response in muller glia during inflammation. Glia, 60(11): 16291645.

Kunos, G., Osei-Hyiaman, D., Batkai, S., Sharkey, K.A., and Makriyannis, A. 2009. Should peripheral $\mathrm{CB}(1)$ cannabinoid receptors be selectively targeted for therapeutic gain? Trends Pharmacol. Sci. 30(1): 1-7.

Kurz, C., Baranowska, U., Lupinski, S., Gothert, M., Malinowska, B., and Schlicker, E. 2009. Urethane, but not pentobarbitone, attenuates presynaptic receptor function in rats: a contribution to the choice of anaesthetic. Br. J. Pharmacol. 157(8): 1474-1482.

Laezza, C., Pisanti, S., Malfitano, A.M., and Bifulco, M. 2008. The anandamide analog, Met-FAEA, controls human breast cancer cell migration via the RHOA/RHO kinase signaling pathway. Endocr. Relat. Cancer, 15(4): 965-974.

Lagneux, C., and Lamontagne, D. 2001. Involvement of cannabinoids in the cardioprotection induced by lipopolysaccharide. Br. J. Pharmacol. 132(4): 793-796.

Lake, K.D., Compton, D.R., Varga, K., Martin, B.R., and Kunos, G. 1997. Cannabinoid-induced hypotension and bradycardia in rats mediated by CB1-like cannabinoid receptors. J. Pharmacol. Exp. Ther. 281(3): 1030-1037.

Lake, K.D., Martin, B.R., Kunos, G., and Varga, K. 1997. Cardiovascular effects of anandamide in anesthetized and conscious normotensive and hypertensive rats. Hypertension, 29(5): 12041210. 
Lan, R., Gatley, J., Lu, Q., Fan, P., Fernando, S.R., Volkow, N.D., et al. 1999. Design and synthesis of the CB1 selective cannabinoid antagonist AM281: a potential human SPECT ligand. AAPS PharmSci. 1(2): E4.

Lan, R., Liu, Q., Fan, P., Lin, S., Fernando, S.R., McCallion, D., et al. 1999. Structure-activity relationships of pyrazole derivatives as cannabinoid receptor antagonists. J. Med. Chem. 42(4): 769-776.

Laprairie, R.B., Kelly, M.E., and Denovan-Wright, E.M. 2013. Cannabinoids increase type 1 cannabinoid receptor expression in a cell culture model of striatal neurons: implications for Huntington's disease. Neuropharmacology, 72: 47-57.

Lastres-Becker, I., Fezza, F., Cebeira, M., Bisogno, T., Ramos, J.A., Milone, A., et al. 2001. Changes in endocannabinoid transmission in the basal ganglia in a rat model of Huntington's disease. Neuroreport, 12(10): 2125-2129.

Latini, L., Bisicchia, E., Sasso, V., Chiurchiu, V., Cavallucci, V., Molinari, M., et al. 2014. Cannabinoid CB2 receptor (CB2R) stimulation delays rubrospinal mitochondrial-dependent degeneration and improves functional recovery after spinal cord hemisection by ERK1/2 inactivation. Cell Death Dis. 5: e1404.

Lauckner, J.E., Hille, B., and Mackie, K. 2005. The cannabinoid agonist WIN55,212-2 increases intracellular calcium via CB1 receptor coupling to Gq/11 G proteins. Proc. Natl. Acad. Sci. U. S. A. 102(52): 19144-19149.

Lepicier, P., Bouchard, J.F., Lagneux, C., and Lamontagne, D. 2003. Endocannabinoids protect the rat isolated heart against ischaemia. Br. J. Pharmacol. 139(4): 805-815.

Li, C., Jones, P.M., and Persaud, S.J. 2011. Role of the endocannabinoid system in food intake, energy homeostasis and regulation of the endocrine pancreas. Pharmacol. Ther. 129(3): 307-320. 
Li, Q., Guo, H.C., Maslov, L.N., Qiao, X.W., Zhou, J.J., and Zhang, Y. 2014. Mitochondrial permeability transition pore plays a role in the cardioprotection of CB2 receptor against ischemia-reperfusion injury. Can. J. Physiol. Pharmacol. 92(3): 205-214.

Li, Q., Shi, M., and Li, B. 2013. Anandamide enhances expression of heat shock protein 72 to protect against ischemia-reperfusion injury in rat heart. J. Physiol. Sci. 63(1): 47-53.

Li, Q., Wang, F., Zhang, Y.M., Zhou, J.J., and Zhang, Y. 2013. Activation of cannabinoid type 2 receptor by JWH133 protects heart against ischemia/reperfusion-induced apoptosis. Cell.

Physiol. Biochem. 31(4-5): 693-702.

Liao, Y., Bin, J., Asakura, M., Xuan, W., Chen, B., Huang, Q., et al. 2012. Deficiency of type 1 cannabinoid receptors worsens acute heart failure induced by pressure overload in mice. Eur. Heart J. 33(24): 3124-3133.

Liao, Y., Bin, J., Luo, T., Zhao, H., Ledent, C., Asakura, M., et al. 2013. CB1 cannabinoid receptor deficiency promotes cardiac remodeling induced by pressure overload in mice. Int. J. Cardiol. 167(5): 1936-1944.

Lile, J.A., Kelly, T.H., and Hays, L.R. 2011. Separate and combined effects of the cannabinoid agonists nabilone and Delta(9)-THC in humans discriminating Delta(9)-THC. Drug Alcohol Depend. 116(1-3): 86-92.

Lin, C.Y., Hsu, Y.J., Hsu, S.C., Chen, Y., Lee, H.S., Lin, S.H., et al. 2015. CB1 cannabinoid receptor antagonist attenuates left ventricular hypertrophy and Akt-mediated cardiac fibrosis in experimental uremia. J. Mol. Cell. Cardiol. 85: 249-261.

Liu, J., Gao, B., Mirshahi, F., Sanyal, A.J., Khanolkar, A.D., Makriyannis, A., et al. 2000. Functional CB1 cannabinoid receptors in human vascular endothelial cells. Biochem. J. 346 Pt 3: $835-840$. 
Lodola, A., Castelli, R., Mor, M., and Rivara, S. 2015. Fatty acid amide hydrolase inhibitors: a patent review (2009-2014). Expert Opin. Ther. Pat. 25(11): 1247-1266.

Lu, Y., Akinwumi, B.C., Shao, Z. and Anderson, H.D. 2014. Ligand activation of cannabinoid receptors attenuates hypertrophy of neonatal rat cardiomyocytes. J. Cardiovasc. Pharmacol. 64(5): $420-430$.

Maccarrone, M., van der Stelt, M., Rossi, A., Veldink, G.A., Vliegenthart, J.F., and Agro, A.F. 1998. Anandamide hydrolysis by human cells in culture and brain. J. Biol. Chem., 273(48): $32332-32339$.

Mackie, K., Devane, W.A., and Hille, B. 1993. Anandamide, an endogenous cannabinoid, inhibits calcium currents as a partial agonist in N18 neuroblastoma cells. Mol. Pharmacol. 44(3): 498-503.

Malan, T.P., Jr., Ibrahim, M.M., Lai, J., Vanderah, T.W., Makriyannis, A., and Porreca, F. 2003. CB2 cannabinoid receptor agonists: pain relief without psychoactive effects? Curr. Opin. Pharmacol. 3(1): 62-67.

Malinowska, B., Kwolek, G., and Gothert, M. 2001. Anandamide and methanandamide induce both vanilloid VR1- and cannabinoid CB1 receptor-mediated changes in heart rate and blood pressure in anaesthetized rats. Naunyn Schmiedebergs Arch. Pharmacol. 364(6): 562-569. Manuel, I., Gonzalez de San Roman, E., Giralt, M.T., Ferrer, I., and Rodriguez-Puertas, R. 2014. Type-1 cannabinoid receptor activity during Alzheimer's disease progression. J. Alzheimers Dis. 42(3): 761-766.

Marco, E.M., Echeverry-Alzate, V., Lopez-Moreno, J.A., Gine, E., Penasco, S., and Viveros, M.P. 2014. Consequences of early life stress on the expression of endocannabinoid-related genes in the rat brain. Behav. Pharmacol. 25(5-6): 547-556. 
Marriott, K.S., and Huffman, J.W. 2008. Recent advances in the development of selective ligands for the cannabinoid $\mathrm{CB}(2)$ receptor. Curr. Top. Med. Chem. 8(3): 187-204.

Marsicano, G., Wotjak, C.T., Azad, S.C., Bisogno, T., Rammes, G., Cascio, M.G., et al. 2002.

The endogenous cannabinoid system controls extinction of aversive memories. Nature, 418(6897): 530-534.

Mastinu, A., Pira, M., Pani, L., Pinna, G.A., and Lazzari, P. 2012. NESS038C6, a novel selective CB1 antagonist agent with anti-obesity activity and improved molecular profile. Behav. Brain Res. 234(2): 192-204.

Mathew, R.J., Wilson, W.H., and Davis, R. 2003. Postural syncope after marijuana: a transcranial Doppler study of the hemodynamics. Pharmacol. Biochem. Behav. 75(2): 309-318. Matias, I., Gonthier, M.P., Orlando, P., Martiadis, V., De Petrocellis, L., Cervino, C., et al. 2006. Regulation, function, and dysregulation of endocannabinoids in models of adipose and betapancreatic cells and in obesity and hyperglycemia. J. Clin. Endocrinol. Metab. 91(8): 3171-3180. Matsuda, L.A., Lolait, S.J., Brownstein, M.J., Young, A.C., and Bonner, T.I. 1990. Structure of a cannabinoid receptor and functional expression of the cloned cDNA. Nature, 346(6284): 561564.

Mazzola, C., Micale, V., and Drago, F. 2003. Amnesia induced by beta-amyloid fragments is counteracted by cannabinoid CB1 receptor blockade. Eur. J. Pharmacol. 477(3): 219-225. McAllister, S.D., and Glass, M. 2002. CB(1) and CB(2) receptor-mediated signalling: a focus on endocannabinoids. Prostaglandins Leukot. Essent. Fatty Acids, 66(2-3): 161-171.

McDougle, D.R., Kambalyal, A., Meling, D.D., and Das, A. 2014. Endocannabinoids anandamide and 2-arachidonoylglycerol are substrates for human CYP2J2 epoxygenase. J. Pharmacol. Exp. Ther. 351(3): 616-627. 
Mechoulam, R., Ben-Shabat, S., Hanus, L., Ligumsky, M., Kaminski, N.E., Schatz, A.R., et al. 1995. Identification of an endogenous 2-monoglyceride, present in canine gut, that binds to cannabinoid receptors. Biochem. Pharmacol. 50(1): 83-90.

Mechoulam, R., Fride, E., Ben-Shabat, S., Meiri, U., and Horowitz, M. 1998. Carbachol, an acetylcholine receptor agonist, enhances production in rat aorta of 2-arachidonoyl glycerol, a hypotensive endocannabinoid. Eur. J. Pharmacol. 362(1): R1-3.

Mechoulam, R., Fride, E., and Di Marzo, V. 1998. Endocannabinoids. Eur. J. Pharmacol. 359(1): $1-18$.

Meiri, E., Jhangiani, H., Vredenburgh, J.J., Barbato, L.M., Carter, F.J., Yang, H.M., et al. 2007. Efficacy of dronabinol alone and in combination with ondansetron versus ondansetron alone for delayed chemotherapy-induced nausea and vomiting. Curr. Med. Res. Opin. 23(3): 533-543. Mendez-Diaz, M., Caynas-Rojas, S., Arteaga Santacruz, V., Ruiz-Contreras, A.E., AguilarRoblero, R., and Prospero-Garcia, O. 2013. Entopeduncular nucleus endocannabinoid system modulates sleep-waking cycle and mood in rats. Pharmacol. Biochem. Behav. 107: 29-35. Mombouli, J.V., Schaeffer, G., Holzmann, S., Kostner, G.M., and Graier, W.F. 1999. Anandamide-induced mobilization of cytosolic Ca2+ in endothelial cells. Br. J. Pharmacol. 126(7): 1593-1600.

Moreira, F.A., Aguiar, D.C., and Guimaraes, F.S. 2007. Anxiolytic-like effect of cannabinoids injected into the rat dorsolateral periaqueductal gray. Neuropharmacology, 52(3): 958-965. Moreira, F.A., Grieb, M., and Lutz, B. 2009. Central side-effects of therapies based on CB1 cannabinoid receptor agonists and antagonists: focus on anxiety and depression. Best Pract. Res. Clin. Endocrinol. Metab. 23(1): 133-144. 
Morena, M., De Castro, V., Gray, J.M., Palmery, M., Trezza, V., Roozendaal, B., et al. 2015. Training-Associated Emotional Arousal Shapes Endocannabinoid Modulation of Spatial Memory Retrieval in Rats. J. Neurosci. 35(41): 13962-13974.

Mukhopadhyay, P., Batkai, S., Rajesh, M., Czifra, N., Harvey-White, J., Hasko, G., et al. 2007. Pharmacological inhibition of CB1 cannabinoid receptor protects against doxorubicin-induced cardiotoxicity. J. Am. Coll. Cardiol. 50(6): 528-536.

Munro, S., Thomas, K.L., and Abu-Shaar, M. 1993. Molecular characterization of a peripheral receptor for cannabinoids. Nature, 365(6441): 61-65.

Murillo-Rodriguez, E., Blanco-Centurion, C., Sanchez, C., Piomelli, D. and Shiromani, P.J. 2003. Anandamide enhances extracellular levels of adenosine and induces sleep: an in vivo microdialysis study. Sleep, 26(8): 943-947.

Murillo-Rodriguez, E., Millan-Aldaco, D., Di Marzo, V., and Drucker-Colin, R. 2008. The anandamide membrane transporter inhibitor, VDM-11, modulates sleep and c-Fos expression in the rat brain. Neuroscience, 157(1), 1-11.

Nathan, P.J., O'Neill, B.V., Napolitano, A., and Bullmore, E.T. 2011. Neuropsychiatric adverse effects of centrally acting antiobesity drugs. CNS Neurosci. Ther. 17(5): 490-505.

Niederhoffer, N., Hansen, H.H., Fernandez-Ruiz, J.J., and Szabo, B. 2001. Effects of cannabinoids on adrenaline release from adrenal medullary cells. Br. J. Pharmacol. 134(6): 13191327.

Nishida, M., Tanabe, S., Maruyama, Y., Mangmool, S., Urayama, K., Nagamatsu, Y., et al. 2005. G alpha 12/13- and reactive oxygen species-dependent activation of c-Jun NH2-terminal kinase and p38 mitogen-activated protein kinase by angiotensin receptor stimulation in rat neonatal cardiomyocytes. J. Biol. Chem. 280(18): 18434-18441. 
Nissen, S.E., Nicholls, S.J., Wolski, K., Rodes-Cabau, J., Cannon, C.P., Deanfield, J.E., et al. 2008. Effect of rimonabant on progression of atherosclerosis in patients with abdominal obesity and coronary artery disease: the STRADIVARIUS randomized controlled trial. JAMA, 299(13): 1547-1560.

Nithipatikom, K., Gomez-Granados, A.D., Tang, A.T., Pfeiffer, A.W., Williams, C.L., and Campbell, W.B. 2012. Cannabinoid receptor type 1 (CB1) activation inhibits small GTPase RhoA activity and regulates motility of prostate carcinoma cells. Endocrinology, 153(1): 29-41. O'Brien, L.D., Limebeer, C.L., Rock, E.M., Bottegoni, G., Piomelli, D., and Parker, L.A. 2013. Anandamide transport inhibition by ARN272 attenuates nausea-induced behaviour in rats, and vomiting in shrews (Suncus murinus). Br. J. Pharmacol. 170(5): 1130-1136.

O'Leary, D.H., Reuwer, A.Q., Nissen, S.E., Despres, J.P., Deanfield, J.E., Brown, M.W., et al. 2011. Effect of rimonabant on carotid intima-media thickness (CIMT) progression in patients with abdominal obesity and metabolic syndrome: the AUDITOR Trial. Heart, 97(14): 11431150.

Onaivi, E.S., Carpio, O., Ishiguro, H., Schanz, N., Uhl, G.R., and Benno, R. 2008. Behavioral effects of CB2 cannabinoid receptor activation and its influence on food and alcohol consumption. Ann. N.Y. Acad. Sci. 1139: 426-433.

Orellana-Serradell, O., Poblete, C.E., Sanchez, C., Castellon, E.A., Gallegos, I., Huidobro, C., et al. 2015. Proapoptotic effect of endocannabinoids in prostate cancer cells. Oncol. Rep. 33(4): 1599-1608.

Osei-Hyiaman, D., DePetrillo, M., Pacher, P., Liu, J., Radaeva, S., Batkai, S., et al. 2005. Endocannabinoid activation at hepatic CB1 receptors stimulates fatty acid synthesis and contributes to diet-induced obesity. J. Clin. Invest. 115(5): 1298-1305. 
Pacher, P., Batkai, S., and Kunos, G. 2004. Haemodynamic profile and responsiveness to anandamide of TRPV1 receptor knock-out mice. J. Physiol. 558(Pt 2): 647-657.

Pacher, P., Batkai, S., and Kunos, G.. 2006. The endocannabinoid system as an emerging target of pharmacotherapy. Pharmacol. Rev. 58(3): 389-462.

Palazuelos, J., Aguado, T., Egia, A., Mechoulam, R., Guzman, M., and Galve-Roperh, I. 2006. Non-psychoactive CB2 cannabinoid agonists stimulate neural progenitor proliferation. FASEB J. 20(13): 2405-2407.

Pava, M.J., den Hartog, C.R., Blanco-Centurion, C., Shiromani, P.J., and Woodward, J.J. 2014. Endocannabinoid modulation of cortical up-states and NREM sleep. PLoS One, 9(2): e88672. Pava, M.J., Makriyannis, A., and Lovinger, D.M. 2016. Endocannabinoid Signaling Regulates Sleep Stability. PLoS One, 11(3): e0152473.

Pertwee, R.G. 1999. Pharmacology of cannabinoid receptor ligands. Curr. Med. Chem. 6(8): $635-664$.

Pertwee, R.G. 2006. The pharmacology of cannabinoid receptors and their ligands: an overview. Int. J. Obes. (Lond.), 30 Suppl 1: S13-18.

Pertwee, R.G. 2008. The diverse CB1 and CB2 receptor pharmacology of three plant cannabinoids: delta9-tetrahydrocannabinol, cannabidiol and delta9-tetrahydrocannabivarin. Br. J. Pharmacol. 153(2): 199-215.

Pertwee, R.G. 2014. Elevating endocannabinoid levels: pharmacological strategies and potential therapeutic applications. Proc. Nutr. Soc. 73(1), 96-105.

Pi-Sunyer, F.X., Aronne, L.J., Heshmati, H.M., Devin, J., Rosenstock, J., and Group RI-NAS. 2006. Effect of rimonabant, a cannabinoid-1 receptor blocker, on weight and cardiometabolic 
risk factors in overweight or obese patients: RIO-North America: a randomized controlled trial. JAMA, 295(7): 761-775.

Piomelli, D. 2003. The molecular logic of endocannabinoid signalling. Nat. Rev. Neurosci. 4(11): 873-884.

Preet, A., Ganju, R.K., and Groopman, J.E. 2008. Delta9-Tetrahydrocannabinol inhibits epithelial growth factor-induced lung cancer cell migration in vitro as well as its growth and metastasis in vivo. Oncogene, 27(3): 339-346.

Price, D.A., Martinez, A.A., Seillier, A., Koek, W., Acosta, Y., Fernandez, E., et al. 2009. WIN55,212-2, a cannabinoid receptor agonist, protects against nigrostriatal cell loss in the 1methyl-4-phenyl-1,2,3,6-tetrahydropyridine mouse model of Parkinson's disease. Eur. J. Neurosci. 29(11): 2177-2186.

Quarta, C., Bellocchio, L., Mancini, G., Mazza, R., Cervino, C., Braulke, L.J., et al. 2010. CB(1) signaling in forebrain and sympathetic neurons is a key determinant of endocannabinoid actions on energy balance. Cell Metab. 11(4), 273-285.

Rajesh, M., Mukhopadhyay, P., Hasko, G., Huffman, J.W., Mackie, K., and Pacher, P. 2008. CB2 cannabinoid receptor agonists attenuate TNF-alpha-induced human vascular smooth muscle cell proliferation and migration. Br. J. Pharmacol. 153(2): 347-357.

Rajesh, M., Mukhopadhyay, P., Hasko, G., and Pacher, P. 2008. Cannabinoid CB1 receptor inhibition decreases vascular smooth muscle migration and proliferation. Biochem. Biophys. Res. Commun. 377(4): 1248-1252.

Rakhshandehroo, M., Sanderson, L.M., Matilainen, M., Stienstra, R., Carlberg, C., de Groot, P.J., et al. 2007. Comprehensive analysis of PPARalpha-dependent regulation of hepatic lipid metabolism by expression profiling. PPAR Res. 2007: 26839. 
Ramirez, B.G., Blazquez, C., Gomez del Pulgar, T., Guzman, M., and de Ceballos, M.L. 2005. Prevention of Alzheimer's disease pathology by cannabinoids: neuroprotection mediated by blockade of microglial activation. J. Neurosci. 25(8): 1904-1913.

Rinaldi-Carmona, M., Barth, F., Heaulme, M., Alonso, R., Shire, D., Congy, C., et al. 1995. Biochemical and pharmacological characterisation of SR141716A, the first potent and selective brain cannabinoid receptor antagonist. Life Sci. 56(23-24): 1941-1947.

Rinaldi-Carmona, M., Barth, F., Millan, J., Derocq, J.M., Casellas, P., Congy, C., et al. 1998. SR 144528, the first potent and selective antagonist of the CB2 cannabinoid receptor. J. Pharmacol. Exp. Ther. 284(2): 644-650.

Romero, T.R.L., Resende, L.C., Guzzo, L.S., and Duarte, I.D.G. 2013. CB1 and CB2 cannabinoid receptor agonists induce peripheral antinociception by activation of the endogenous noradrenergic system. Anesth. Analg. 116(2): 463-472.

Ross, R.A. 2003. Anandamide and vanilloid TRPV1 receptors. Br. J. Pharmacol 140(5): 790801.

Ross, R.A., Brockie, H.C., Stevenson, L.A., Murphy, V.L., Templeton, F., Makriyannis, A., et al. 1999. Agonist-inverse agonist characterization at CB1 and CB2 cannabinoid receptors of L759633, L759656, and AM630. Br. J. Pharmacol. 126(3): 665-672.

Rouzer, C.A., and Marnett, L.J. 2011. Endocannabinoid oxygenation by cyclooxygenases, lipoxygenases, and cytochromes P450: cross-talk between the eicosanoid and endocannabinoid signaling pathways. Chem. Rev. 111(10), 5899-5921.

Rubino, T., Guidali, C., Vigano, D., Realini, N., Valenti, M., Massi, P., et al. 2008. CB1 receptor stimulation in specific brain areas differently modulate anxiety-related behaviour. Neuropharmacology, 54(1): 151-160. 
Ryberg, E., Larsson, N., Sjogren, S., Hjorth, S., Hermansson, N.O., Leonova, J., et al. 2007. The orphan receptor GPR55 is a novel cannabinoid receptor. Br. J. Pharmacol. 152(7): 1092-1101. Saario, S.M., Savinainen, J.R., Laitinen, J.T., Jarvinen, T., and Niemi, R.. 2004. Monoglyceride lipase-like enzymatic activity is responsible for hydrolysis of 2-arachidonoylglycerol in rat cerebellar membranes. Biochem. Pharmacol. 67(7): 1381-1387.

Sagredo, O., Gonzalez, S., Aroyo, I., Pazos, M.R., Benito, C., Lastres-Becker, I., et al. 2009. Cannabinoid CB2 receptor agonists protect the striatum against malonate toxicity: relevance for Huntington's disease. Glia, 57(11): 1154-1167.

Sanchez, C., de Ceballos, M.L., Gomez del Pulgar, T., Rueda, D., Corbacho, C., Velasco, G., et al. 2001. Inhibition of glioma growth in vivo by selective activation of the $\mathrm{CB}(2)$ cannabinoid receptor. Cancer Res. 61(15): 5784-5789.

Sanchez Lopez, A.J., Roman-Vega, L., Ramil Tojeiro, E., Giuffrida, A., and Garcia-Merino, A. 2015. Regulation of cannabinoid receptor gene expression and endocannabinoid levels in lymphocyte subsets by interferon-beta: a longitudinal study in multiple sclerosis patients. Clin. Exp. Immunol. 179(1): 119-127.

Santucci, V., Storme, J.J., Soubrie, P., and Le Fur, G. 1996. Arousal-enhancing properties of the CB1 cannabinoid receptor antagonist SR $141716 \mathrm{~A}$ in rats as assessed by electroencephalographic spectral and sleep-waking cycle analysis. Life Sci. 58(6): PL103-110. Scheen, A.J., Finer, N., Hollander, P., Jensen, M.D., Van Gaal, L.F., and Group RI-DS. 2006. Efficacy and tolerability of rimonabant in overweight or obese patients with type 2 diabetes: a randomised controlled study. Lancet, 368(9548): 1660-1672. 
Schmid, P.C., Krebsbach, R.J., Perry, S.R., Dettmer, T.M., Maasson, J.L., and Schmid, H.H. 1995. Occurrence and postmortem generation of anandamide and other long-chain Nacylethanolamines in mammalian brain. FEBS Lett. 375(1-2): 117-120.

Senogles, S.E. 2000. The D2s dopamine receptor stimulates phospholipase D activity: a novel signaling pathway for dopamine. Mol. Pharmacol. 58(2): 455-462.

Sharkey, K.A., Darmani, N.A., and Parker, L.A. 2014. Regulation of nausea and vomiting by cannabinoids and the endocannabinoid system. Eur. J. Pharmacol. 722, 134-146.

Shen, M., and Thayer, S.A. 1998. The cannabinoid agonist Win55,212-2 inhibits calcium channels by receptor-mediated and direct pathways in cultured rat hippocampal neurons. Brain Res. 783(1): 77-84.

Showalter, V.M., Compton, D.R., Martin, B.R., and Abood, M.E. 1996. Evaluation of binding in a transfected cell line expressing a peripheral cannabinoid receptor (CB2): identification of cannabinoid receptor subtype selective ligands. J. Pharmacol. Exp. Ther. 278(3): 989-999. Siegmund, S.V., Qian, T., de Minicis, S., Harvey-White, J., Kunos, G., Vinod, K.Y., et al. 2007. The endocannabinoid 2-arachidonoyl glycerol induces death of hepatic stellate cells via mitochondrial reactive oxygen species. FASEB J. 21(11): 2798-2806.

Skaper, S.D., Buriani, A., Dal Toso, R., Petrelli, L., Romanello, S., Facci, L., et al. 1996. The ALIAmide palmitoylethanolamide and cannabinoids, but not anandamide, are protective in a delayed postglutamate paradigm of excitotoxic death in cerebellar granule neurons. Proc. Natl. Acad. Sci. U. S. A. 93(9): 3984-3989.

Steffens, S., Veillard, N.R., Arnaud, C., Pelli, G., Burger, F., Staub, C., et al. 2005. Low dose oral cannabinoid therapy reduces progression of atherosclerosis in mice. Nature, 434(7034): 782786. 
Stella, N., and Piomelli, D. 2001. Receptor-dependent formation of endogenous cannabinoids in cortical neurons. Eur. J. Pharmacol. 425(3): 189-196.

Stella, N., Schweitzer, P., and Piomelli, D. 1997. A second endogenous cannabinoid that modulates long-term potentiation. Nature, 388(6644): 773-778.

Storr, M., Keenan, C., Zhang, H., Patel, K., Makriyannis, A., and Sharkey, K. 2009. Activation of the cannabinoid 2 receptor (CB2) protects against experimental colitis. Inflamm. Bowel Dis. 15(11), 1678-1685.

Storr, M.A., Keenan, C.M., Zhang, H., Patel, K.D., Makriyannis, A., and Sharkey, K.A. 2009. Activation of the cannabinoid 2 receptor (CB2) protects against experimental colitis. Inflamm. Bowel Dis. 15(11): 1678-1685.

Sugamura, K., Sugiyama, S., Fujiwara, Y., Matsubara, J., Akiyama, E., Maeda, H., et al. 2010. Cannabinoid 1 receptor blockade reduces atherosclerosis with enhances reverse cholesterol transport. J. Atheroscler. Thromb. 17(2): 141-147.

Sugiura, T., Kondo, S., Sukagawa, A., Tonegawa, T., Nakane, S., Yamashita, A., et al. 1996. Transacylase-mediated and phosphodiesterase-mediated synthesis of Narachidonoylethanolamine, an endogenous cannabinoid-receptor ligand, in rat brain microsomes. Comparison with synthesis from free arachidonic acid and ethanolamine. Eur. J. Biochem. $240(1), 53-62$.

Szaflarski, J.P., and Bebin, E.M. 2014. Cannabis, cannabidiol, and epilepsy--from receptors to clinical response. Epilepsy Behav. 41: 277-282.

Tam, J., Vemuri, V.K., Liu, J., Batkai, S., Mukhopadhyay, B., Godlewski, G., et al. 2010. Peripheral CB1 cannabinoid receptor blockade improves cardiometabolic risk in mouse models of obesity. J. Clin. Invest. 120(8): 2953-2966. 
Tedesco, L., Valerio, A., Dossena, M., Cardile, A., Ragni, M., Pagano, C., et al. 2010. Cannabinoid receptor stimulation impairs mitochondrial biogenesis in mouse white adipose tissue, muscle, and liver: the role of eNOS, p38 MAPK, and AMPK pathways. Diabetes, 59(11): 2826-2836.

Thomas, A., Baillie, G.L., Phillips, A.M., Razdan, R.K., Ross, R.A., and Pertwee, R.G. 2007. Cannabidiol displays unexpectedly high potency as an antagonist of CB1 and CB2 receptor agonists in vitro. Br. J. Pharmacol. 150(5): 613-623.

Torres, S., Lorente, M., Rodriguez-Fornes, F., Hernandez-Tiedra, S., Salazar, M., GarciaTaboada, E., et al. 2011. A combined preclinical therapy of cannabinoids and temozolomide against glioma. Mol. Cancer Ther. 10(1): 90-103.

Toth, A., Blumberg, P.M., and Boczan, J. 2009. Anandamide and the vanilloid receptor (TRPV1). Vitam. Horm. 81: 389-419.

Tourino, C., Oveisi, F., Lockney, J., Piomelli, D., and Maldonado, R. 2010. FAAH deficiency promotes energy storage and enhances the motivation for food. Int. J. Obes. (Lond.), 34(3): 557568.

Ueda, N., Yamanaka, K., and Yamamoto, S. 2001. Purification and characterization of an acid amidase selective for $\mathrm{N}$-palmitoylethanolamine, a putative endogenous anti-inflammatory substance. J. Biol. Chem. 276(38): 35552-35557.

Valdeolivas, S., Satta, V., Pertwee, R.G., Fernandez-Ruiz, J., and Sagredo, O. 2012. Sativex-like combination of phytocannabinoids is neuroprotective in malonate-lesioned rats, an inflammatory model of Huntington's disease: role of CB1 and CB2 receptors. ACS Chem. Neurosci. 3(5): 400406. 
Valk, P.J., and Delwel, R. 1998. The peripheral cannabinoid receptor, Cb2, in retrovirallyinduced leukemic transformation and normal hematopoiesis. Leuk. Lymphoma, 32(1-2): 29-43. Van Der Stelt, M., and Di Marzo, V. 2004. Endovanilloids. Putative endogenous ligands of transient receptor potential vanilloid 1 channels. Eur. J. Biochem. 271(10): 1827-1834. Van Gaal, L.F., Rissanen, A.M., Scheen, A.J., Ziegler, O., Rossner, S., and Group RI-ES. 2005. Effects of the cannabinoid-1 receptor blocker rimonabant on weight reduction and cardiovascular risk factors in overweight patients: 1-year experience from the RIO-Europe study. Lancet, 365(9468): 1389-1397.

Van Sickle, M.D., Duncan, M., Kingsley, P.J., Mouihate, A., Urbani, P., Mackie, K., et al. 2005. Identification and functional characterization of brainstem cannabinoid CB2 receptors. Science, 310(5746), 329-332.

Verty, A.N., Allen, A.M., and Oldfield, B.J. 2009. The effects of rimonabant on brown adipose tissue in rat: implications for energy expenditure. Obesity (Silver Spring), 17(2): 254-261. Verty, A.N., Stefanidis, A., McAinch, A.J., Hryciw, D.H., and Oldfield, B. 2015. Anti-Obesity Effect of the CB2 Receptor Agonist JWH-015 in Diet-Induced Obese Mice. PLoS One, 10(11): e0140592.

Vijayakumar, R.S., Lin, Y., Shia, K.S., Yeh, Y.N., Hsieh, W.P., Hsiao, W.C., et al. 2012. Induction of fatty acid oxidation resists weight gain, ameliorates hepatic steatosis and reduces cardiometabolic risk factors. Int. J. Obes. (Lond.), 36(7): 999-1006.

Viveros, M.P., Marco, E.M., and File, S.E. 2005. Endocannabinoid system and stress and anxiety responses. Pharmacol. Biochem. Behav. 81(2): 331-342.

Wagner, J.A., Hu, K., Karcher, J., Bauersachs, J., Schafer, A., Laser, M., et al. 2003. CB(1) cannabinoid receptor antagonism promotes remodeling and cannabinoid treatment prevents 
endothelial dysfunction and hypotension in rats with myocardial infarction. Br. J. Pharmacol. 138(7): 1251-1258.

Walker, J.M., Huang, S.M., Strangman, N.M., Tsou, K., and Sanudo-Pena, M.C. 1999. Pain modulation by release of the endogenous cannabinoid anandamide. Proc. Natl. Acad. Sci. U. S. A. 96(21): 12198-12203.

Wang, P.F., Jiang, L.S., Bu, J., Huang, X.J., Song, W., Du, Y.P., et al. 2012. Cannabinoid-2 receptor activation protects against infarct and ischemia-reperfusion heart injury. J. Cardiovasc. Pharmacol. 59(4): 301-307.

Watanabe, S., Doshi, M., and Hamazaki, T. 2003. n-3 Polyunsaturated fatty acid (PUFA) deficiency elevates and n-3 PUFA enrichment reduces brain 2-arachidonoylglycerol level in mice. Prostaglandins Leukot. Essent. Fatty Acids, 69(1): 51-59.

Wei, B.Q., Mikkelsen, T.S., McKinney, M.K., Lander, E.S., and Cravatt, B.F. 2006. A second fatty acid amide hydrolase with variable distribution among placental mammals. J. Biol. Chem. 281(48): 36569-36578.

Weis, F., Beiras-Fernandez, A., Sodian, R., Kaczmarek, I., Reichart, B., Beiras, A., et al. 2010. Substantially altered expression pattern of cannabinoid receptor 2 and activated endocannabinoid system in patients with severe heart failure. J. Mol. Cell. Cardiol. 48(6): 1187-1193.

Wood, J.T., Williams, J.S., Pandarinathan, L., Janero, D.R., Lammi-Keefe, C.J., and Makriyannis, A. 2010. Dietary docosahexaenoic acid supplementation alters select physiological endocannabinoid-system metabolites in brain and plasma. J. Lipid Res. 51(6): 1416-1423.

Wright, K., Rooney, N., Feeney, M., Tate, J., Robertson, D., Welham, M., et al. 2005. Differential expression of cannabinoid receptors in the human colon: cannabinoids promote epithelial wound healing. Gastroenterology, 129(2): 437-453. 
Yang, H., Zhou, J., and Lehmann, C. 2016. GPR55 - a putative "type 3" cannabinoid receptor in inflammation. J. Basic Clin. Physiol. Pharmacol. 27(3): 297-302

Zaccagnino, P., Corcelli, A., Baronio, M., and Lorusso, M. 2011. Anandamide inhibits oxidative phosphorylation in isolated liver mitochondria. FEBS Lett. 585(2): 429-434.

Zajicek, J., Ball, S., Wright, D., Vickery, J., Nunn, A., Miller, D., et al. 2013. Effect of dronabinol on progression in progressive multiple sclerosis (CUPID): a randomised, placebocontrolled trial. Lancet Neurol. 12(9): 857-865.

Zhao, Y., Liu, Y., Zhang, W., Xue, J., Wu, Y.Z., Xu, W., et al. 2010. WIN55212-2 ameliorates atherosclerosis associated with suppression of pro-inflammatory responses in ApoE-knockout mice. Eur. J. Pharmacol. 649(1-3): 285-292.

Zhao, Y., Yuan, Z., Liu, Y., Xue, J., Tian, Y., Liu, W., et al. 2010. Activation of cannabinoid CB2 receptor ameliorates atherosclerosis associated with suppression of adhesion molecules. J. Cardiovasc. Pharmacol. 55(3): 292-298.

Zheng, X., Sun, T., and Wang, X. 2013. Activation of type 2 cannabinoid receptors (CB2R) promotes fatty acid oxidation through the SIRT1/PGC-1alpha pathway. Biochem. Biophys. Res. Commun. 436(3): 377-381.

Zuurman, L., Ippel, A.E., Moin, E., and van Gerven, J.M. 2009. Biomarkers for the effects of cannabis and THC in healthy volunteers. Br. J. Clin. Pharmacol. 67(1): 5-21.

Zygmunt, P.M., Petersson, J., Andersson, D.A., Chuang, H., Sorgard, M., Di Marzo, V., et al. 1999. Vanilloid receptors on sensory nerves mediate the vasodilator action of anandamide.

Nature, 400(6743): 452-457. 
Table 1. Cannabinoid receptor agonists.

\begin{tabular}{|c|c|c|c|c|}
\hline $\begin{array}{l}\text { Cannabinoid } \\
\text { agonists }\end{array}$ & Description & $\begin{array}{c}\text { Ki for } \\
\text { CB1 (nM) }\end{array}$ & $\begin{array}{c}\text { Ki for CB2 } \\
(n M)\end{array}$ & References \\
\hline $2-A G$ & $\begin{array}{l}\mathrm{CB} 1 \text { and } \mathrm{CB} 2 \\
\text { agonist }\end{array}$ & 472 & 1400 & (Stella et al. 1997) \\
\hline ACEA & $\begin{array}{l}\text { CB1-selective } \\
\text { agonist }\end{array}$ & 1.4 & 3100 & $\begin{array}{c}\text { (Hillard et al. } \\
\text { 1999) }\end{array}$ \\
\hline AM1241 & $\begin{array}{l}\text { CB2-selective } \\
\text { agonist }\end{array}$ & 280 & 3.4 & $\begin{array}{l}\text { (Ibrahim et al. } \\
\text { 2003) }\end{array}$ \\
\hline Anandamide & $\begin{array}{l}\mathrm{CB} 1 \text { and } \mathrm{CB} 2 \\
\text { agonist }\end{array}$ & 89 & 371 & (Pertwee 1999) \\
\hline CB13 & $\begin{array}{l}\text { Peripherally- } \\
\text { restricted CB1 and } \\
\text { CB2 agonist }\end{array}$ & 6.1 & 27.9 & $\begin{array}{c}\text { (Dziadulewicz et } \\
\text { al. 2007) }\end{array}$ \\
\hline CP55940 & $\begin{array}{c}\mathrm{CB} 1 \text { and } \mathrm{CB} 2 \\
\text { agonist }\end{array}$ & 3.72 & 2.55 & $\begin{array}{c}\text { (Felder et al. } \\
1995)\end{array}$ \\
\hline HU-210 & $\begin{array}{l}\mathrm{CB} 1 \text { and } \mathrm{CB} 2 \\
\text { agonist }\end{array}$ & 0.061 & 0.52 & $\begin{array}{c}\text { (Felder et al. } \\
1995)\end{array}$ \\
\hline JWH015 & $\begin{array}{c}\mathrm{CB} 1 \text { and } \mathrm{CB} 2 \\
\text { agonist }\end{array}$ & 383 & 13.8 & $\begin{array}{c}\text { (Showalter et al. } \\
1996)\end{array}$ \\
\hline JWH133 & $\begin{array}{l}\text { CB2-selective } \\
\text { agonist }\end{array}$ & 677 & 3.4 & $\begin{array}{c}\text { (Huffman et al. } \\
\text { 1999) }\end{array}$ \\
\hline $\begin{array}{c}\mathrm{R}- \\
\text { methanandamide }\end{array}$ & $\begin{array}{l}\mathrm{CB} 1 \text { and } \mathrm{CB} 2 \\
\text { agonist }\end{array}$ & 20 & 815 & $\begin{array}{c}\text { (Abadji et al. } \\
\text { 1994; Khanolkar } \\
\text { et al. 1996), }\end{array}$ \\
\hline $\mathrm{THC}$ & $\begin{array}{l}\mathrm{CB} 1 \text { and } \mathrm{CB} 2 \\
\text { agonist }\end{array}$ & 53.3 & 75.3 & $\begin{array}{c}\text { (Felder et al. } \\
\text { 1995) }\end{array}$ \\
\hline WIN55, 212-2 & $\begin{array}{l}\mathrm{CB} 1 \text { and } \mathrm{CB} 2 \\
\text { agonist }\end{array}$ & 3.3 & 62.3 & $\begin{array}{c}\text { (Felder et al. } \\
1995)\end{array}$ \\
\hline
\end{tabular}


Table 2. Cannabinoid receptor antagonists.

\begin{tabular}{|c|c|c|c|c|}
\hline $\begin{array}{l}\text { Cannabinoid } \\
\text { antagonists }\end{array}$ & Description & $\begin{array}{l}\text { Ki for CB1 } \\
(\mathrm{nM})\end{array}$ & $\begin{array}{l}\text { Ki for CB2 } \\
(\mathrm{nM})\end{array}$ & References \\
\hline AM251 & $\begin{array}{l}\text { CB1-selective } \\
\text { antagonist }\end{array}$ & 7.5 & 2290 & $\begin{array}{c}\text { (Lan, Liu, et al. } \\
\text { 1999) }\end{array}$ \\
\hline AM281 & $\begin{array}{l}\text { CB1-selective } \\
\text { antagonist }\end{array}$ & 12 & 4200 & $\begin{array}{l}\text { (Lan, Gatley, et } \\
\text { al. 1999) }\end{array}$ \\
\hline AM630 & $\begin{array}{l}\text { CB2-selective } \\
\text { antagonist }\end{array}$ & 5200 & 31.2 & (Ross et al. 1999) \\
\hline SR141716 & $\begin{array}{l}\text { CB1-selective } \\
\text { antagonist }\end{array}$ & 2 & $>1000$ & $\begin{array}{l}\text { (Rinaldi-Carmona } \\
\text { et al. 1995) }\end{array}$ \\
\hline SR144528 & $\begin{array}{l}\text { CB2-selective } \\
\text { antagonist }\end{array}$ & 400 & 0.6 & $\begin{array}{c}\text { (Rinaldi-Carmona } \\
\text { et al. 1998) }\end{array}$ \\
\hline AM6545 & $\begin{array}{c}\text { Peripherally- } \\
\text { restricted CB1- } \\
\text { selective antagonist }\end{array}$ & 1.7 & 523 & $\begin{array}{c}\text { (Cluny et al. } \\
\text { 2010) }\end{array}$ \\
\hline
\end{tabular}


Figure 1. Synthesis and degradation of 2-AG and anandamide.

Adapted with permission from (El Manira and Kyriakatos 2010). 


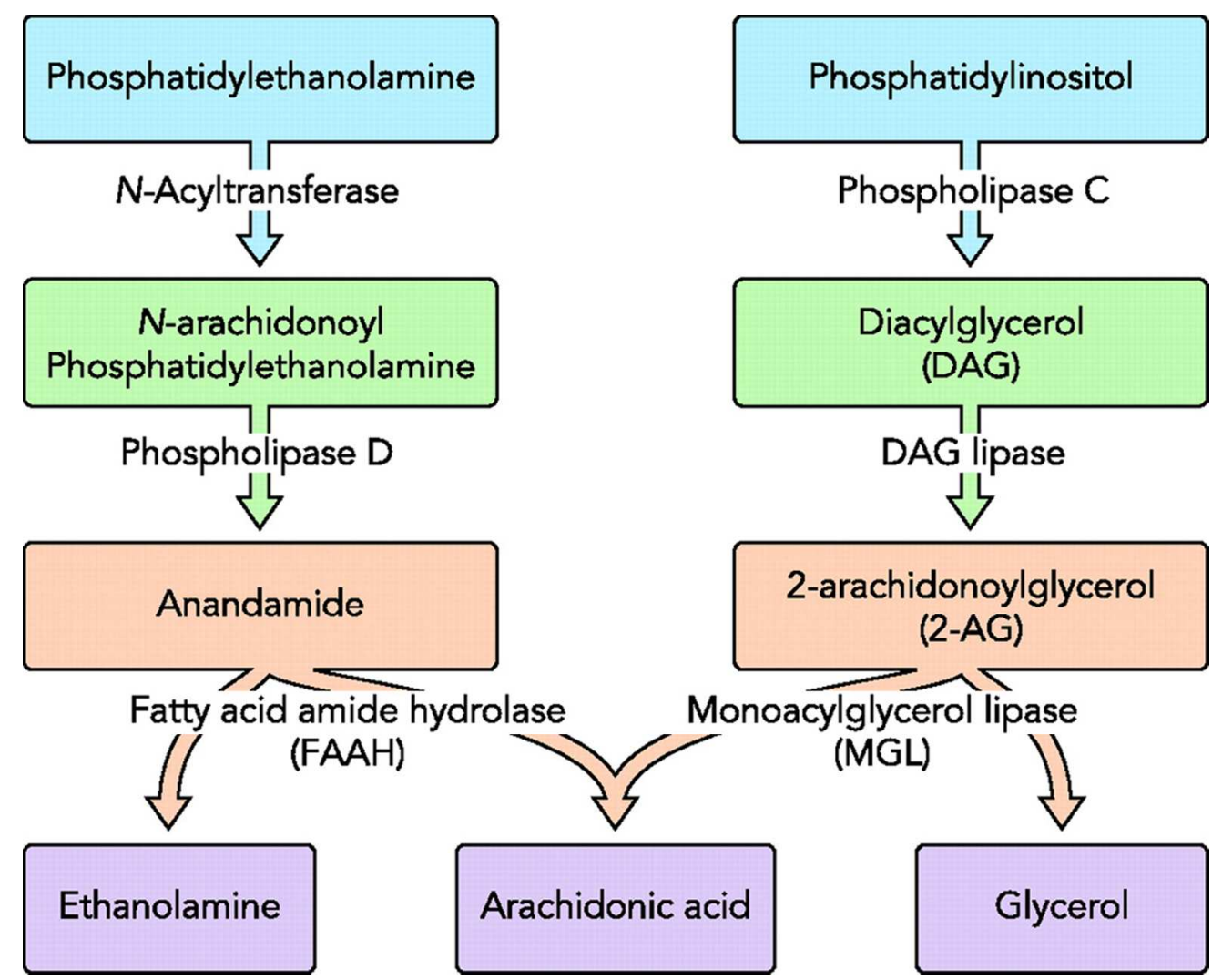

Figure 1. Synthesis and degradation of 2-AG and anandamide. Adapted with permission from (El Manira \& Kyriakatos, 2010).

$182 \times 147 \mathrm{~mm}(300 \times 300$ DPI $)$ 